\title{
Pirrhiese Oorwinning Die Oorlog in Kosovo
}

\author{
DR LEOPOLD SCHOLTZ \\ Senior Adjunk-redakteur van Die Burger \\ DRS INGRID SCHOLTZ \\ Departement Joernalistiek, Universiteit van Stellenbosch
}

\section{INLEIDING}

Net soos elke historiese gebeurtenis is elke oorlog uniek. Tog vertoon die oorlog in Kosovo soveel eienskappe wat totaal afwyk van feitlik elke vorige oorlog in die geskiedenis dat dit die moeite kan loon om dit van nader te bekyk.

So was daar min oorloë - dalk geen enkele - wat in soveel omstredenheid ontvang en gebore is en so 'n enorme openbare debat (en veral kritiek) uitgelok het. Dié uitlating van die Britse krygshistorikus Alistair Horne is tipies van die fiole van toorn wat wêreldwyd oor die hoofde van die beplanners en uitvoerders van Operasie Allied Force uitgestort is: "Like many people of my generation who know Yugoslavia, the past two months have made me utterly miserable. As a military historian having written about many wars, and served in one, I cannot recall any campaign that I have disliked so much."'

Dit was die eerste oorlog in die ganse geskiedenis wat (in elk geval aan Navo se kant) nie soseer om redes van harde strategiese eiebelang gevoer is nie, maar om 'n "sagte" rede soos menseregte. En dit het aanleiding gegee tot 'n nuwe internasionale politieke leer op grond waarvan sekere groot moondhede hulle nou die reg toe-eien om in die binnelandse aangeleenthede van soewereine state in te gryp wanneer menseregte verkrag word. Op operasionele vlak was dit die eerste oorlog in die geskiedenis waar die finale uitklophou nie deur 'n grondoffensief gegee moes word nie, waar die wenners feitlik uitsluitend op lugaanvalle staatgemaak het, en waar die wenners geen enkele ongeval in gevegte gely het nie.

Dis ook duidelik dat die oorlog 'n fundamentele keerpunt in die ná-Koue-Oorlogse geskiedenis beteken. Trouens, 'n mens kan redeneer dat dit die einde van die ná-KoueOorlogse era was en die begin van 'n nuwe, nog ondefinieerbare historiese fase ingelui het. Dié feit, so sal ons verder sien, was een van die belangrikste redes waarom die oorlog die katalisator geword het om Rusland en China drasties van die Weste te vervreem.

Alistair Horne: "Was the 'incompetent swatting from above the clouds' worth it? (Sunday Argus, 20.6.1999). 


\section{DIE HISTORIESE AGTERGROND}

28 Junie 1389: die legendariese Serwiese leier, prins Lazar, word op die Vlakte van die Merels - in Serwies Kosovo Polje - net buite die hoofstad van Kosovo, Pristina, deur die Turkse magte verslaan. ${ }^{2}$

April 1987: Slobodan Milosevic, tot die tyd 'n onbekende politikus, roep voor 'n opgewonde menigte etniese Serwiërs in Kosovo uit: "Joego-Slawië kan nie sonder Kosovo bestaan nie! Niemand mag dit waag om julle te verslaan nie!"

Eersgenoemde gebeurtenis het vir die moderne Serwiërs, ondanks die feit dat dit 500 jaar se Moslem-oorheersing ingelui het, die sentrale simbool van verset teen 'n almagtige vyand geword. Die tweede voorval het 'n opportunistiese magspolitikus die kans gegee om hom as 'n tweede prins Lazar voor te doen en die magtigste man in Serwië te word, met rampsalige gevolge vir sy volk en 'n groot deel van die Balkan.

Om die fundamentele verband tussen dié twee gebeurtenisse asook die redes vir die Serwiërs se steun aan iemand soos Milosevic werklik te verstaan, is dit noodsaaklik om kortliks 'n blik te werp op die geskiedenis van die Serwiërs.

Daar is eintlik vier belangrike feite wat 'n mens voortdurend met betrekking tot die Balkan, en meer spesifiek die Serwiërs, in gedagte moet hou: die eerste is dat die gebied op die breukvlak van drie belangrike wereldgodsdienste lê - die Christelike Rooms-Katolieke en Oosters-Ortodokse kerke en die Islam. Die tweede is dat die Balkan reeds vanaf sy vroegste geskiedenis die speelbal was van groot ryke in die omgewing, veral die Grieks-Ortodokse Bisantynse Ryk, sy opvolger, die Islamitiese Turkse of Ottomaanse Ryk, die RoomsKatolieke Oostenryk-Hongarye en die Ortodokse Russiese Ryk.

Die derde feit is die stryd om onafhanklikheid wat vanaf die negentiende eeu deur die Balkanvolke teen die oorheersing van die Turke en die Oostenrykers gevoer is. Hierby moet in gedagte gehou word dat dié stryd ook voortdurend met onderlinge konflikte tussen die volke op die Balkan gepaard gegaan het. Ten slotte - en dit is die laaste, maar seker nie die onbelangrikste feit nie - het die onderlinge rusies en voortdurende inmenging van buite veroorsaak dat byna elke Balkanstaat vandag aansienlike minderhede binne sy grense huisves.

Die feit dat die Serwiërs saam met die grootste deel van die volke op die Balkan met uitsondering van die Kroate en Slowene wat Rooms-Katoliek geword het - in die tiende eeu n.C. vanuit Bisantium tot die Christelike geloof bekeer is, is van fundamentele belang om die latere gebeurtenisse op die Balkan te verstaan. Dit het weliswaar nie verhinder dat die Serwiese koninkryk in 'n voortdurende stryd om die mag met sy Ortodokse bure gewikkel was nie. Maar toe die verskillende Balkan-koninkrykies in die veertiende eeu deur die

2 Kyk onder meer Katherine Verdery: The Political Lives of Dead Bodies. Reburial and PostSocialist Change (New York, Columbia University Press, 1999); Maria Tedorov: Imagining the Balkans (Oxford, Oxford University Press, 1997); Robert D. Kaplan: Balkan Ghosts (New York, Random House, 1994); Noel Malcolm: Kosovo: A Short History (New York, New York University Press, 1998). 
Ottomaanse stewel vertrap is, was dit byna vanselfsprekend dat hulle hul mettertyd tot hul steeds magtiger buurman in die ooste gewend het, te wete die Russiese Ryk waarmee hulle 'n etniese afstamming en godsdiens gedeel het.

Die Russe het wel hul eie geopolitieke en strategiese redes gehad om die mag van die Turke terug te dring en te ondermyn, maar in die negentiende eeu het hulle hul natuurlike uitbreidingsdrang na die suidweste ook 'n ideologiese fondament gegee: die ekstreemnasionalistiese Pan-Slawisme. Dié beweging het daarna gestreef om al die Slawe, uiteraard onder leiding van die Russe, polities te verenig en in die proses die Ottomaanse - en die Oostenryks-Hongaarse Ryk wat sy eie magspel in die Balkan gespeel het - te vernietig.

Teen dié agtergrond word die baie fel pro-Serwiese reaksie van die Russe - wat bowendien ná die val van die eens so magtige Sowjet-ryk die vernedering moes smaak dat hulle op die wêreldtoneel tot 'n derderangse moondheid gereduseer is - op die Navobombardemente van Joego-Slawië heeltemal verstaanbaar. Navo het as 't ware die opvolger geword van Rusland se ou vyande, die Moslems en die Rooms-Katolieke OostenrykHongarye.

Die verowering van die Balkan deur die Turke in die veertiende eeu het nie alleen die nasionalistiese gevoelens van die Serwiërs aangeblaas nie, maar sake in dié gebied nog ingewikkelder gemaak. Baie politieke leiers en adellikes het Moslems geword. Die bevolking het egter meestal Ortodoks gebly. Die grootste uitsondering op dié reël is die Albanese. Ook die huidige Bosnië-Herzegovina het 'n aansienlike Moslem minderheid. Dit is egter teen die agtergrond van die jongste konflikte amper ironies dat die meeste bekeerlinge dit om politieke redes gedoen en dat hulle eintlik maar "eina-Moslems" was.

In die loop van die agtiende eeu het die mag van die Ottomaanse Ryk begin taan en in die negentiende eeu het die Europeërs hom selfs die "siek man van Europa" genoem. Opkomende nywerheidslande soos Brittanje en Frankryk, maar ook ou ryke soos Rusland en Oostenryk-Hongarye het soos roofdiere hul lippe reeds begin aflek om die Turkse buit in Afrika, die Midde-Ooste en die Balkan te verdeel.

'n Hele reeks opstande, internasionale verdrae en kongresse, waartydens grense steeds opnuut getrek en onbevredigende kompromisse gesluit is, het in die begin van die twintigste eeu 'n baie verwarrende situasie in die Balkan geskep. Dit was die Serwiërs wat die dryfkrag was agter die groeiende beweging onder die bewoners van die vier laasgenoemde gebiede om hulself binne een staatsverband, Joego(Suid)-Slawië, te verenig en as gevolg daarvan voortdurend krisisse op die Balkan veroorsaak het. Op 28 Junie 1914 het 'n Bosniese student, Gavrilo Princip, die Oostenrykse troonopvolger, aartshertog Franz Ferdinand, in Sarajewo vermoor en die begin van die Eerste Wêreldoorlog ingelui.

In 1918, aan die einde van die Eerste Wereldoorlog, is die koninkryk Joego-Slawië op die ruïnes van die Oostenryks-Hongaarse Ryk opgerig. Dit het uit die Oostenrykse provinsies Slowenië, Kroasië en Bosnië- Herzegovina, die onafhanklike Serwië, Montenegro en dele van Macedonië bestaan. In die Tweede Wêreldoorlog is die land deur Duitse troepe, met die hulp 
van Bulgarye, Hongarye en Italië, besct. Kroasië het 'n marionetstaat van die Duitsers geword en vreeslik onder die Serwiërs te kere gegaan.

Die Serwiërs het onder leiding van Josip Broz, beter bekend onder sy oorlogsnaam Tito, 'n guerrilla-oorlog teen die Duitsers begin. Hulle is die enigste volk in Europa wat hulself van die Duitse besetting bevry het. Daardeur het die Sosialistiese Federale Republiek van Joego-Slawië - bestaande uit die republieke van Bosnië-Herzegovina, Kroasië, Macedonië, Montenegro, Serwië en Slowenië en twee outonome Serwiese provinsies, Kosovo en Vojvodina - wat deur Tito in 1945 uitgeroep is, altyd betreklik onafhanklik gebly en nooit werklik deel van die Sowjetblok geword nie.

Binnelands het Tito deur 'n fyn spel van verdeel en heers, magspolitiek en toegewings, die verskillende groepe van sy republiek bymekaar gehou. Ná sy dood in 1980 het dié beleid begin uitrafel. In 1989 het die Serwiese regering, toe reeds onder leiding van Milosevic, 'n opstand van die minderheid Serwiërs in Kroasië teen die plaaslike bewind in dié deelstaat gesteun en terselfdertyd die outonomie van Kosovo herroep. Twee jaar later het Slowenië en Kroasië hulself onafhanklik verklaar, wat 'n bloedige konflik tot gevolg gehad en die eerste vlugtelingprobleem geskep het. In dieselfde jaar het die internasionale gemeenskap die twee lande se onafhanklikheid amptelik erken. In 1992 het ook Bosnië-Herzegovina sy onafhanklikheid uitgeroep, maar dié daad is gevolg deur 'n drie jaar lange bloedige burgeroorlog tussen die plaaslike Serwiërs, Kroate en Moslems, wat die lewens van sowat 250000 mense gekos en miljoene van huis en haard verdryf het. Slegs die aanwesigheid van 'n internasionale vredesmag verhoed op die oomblik dat die brose vrede weer verbreek word.

Tans is die buitewereld opnuut betrek by die soveelste konflik in die Balkan. En opnuut is oplossings ontwykend, is die ou haat, die mites en die felle nasionalisme nog springlewendig.

\section{DIE KONFLIK OP STRATEGIESE VLAK}

Operasie Hoefyster: Terugskouende meen die meeste waarnemers dat Milosevic einde 1998 besluit het om Operacija Potkovica - Operasie Hoefyster, die etniese suiwering van Kosovo - van stapel te stuur. Verskeie koerante en tydskrifte het die operasie en die beplanning wat dit voorafgegaan het, probeer rekonstrueer ${ }^{3}$ en die volgende opsomming sal waarskynlik nie ver van die waarheid wees nie:

In der waarheid moet die onmiddellike wortels van die operasie én Navo se reaksie daarop gesoek word in die gebeure van Oktober 1998, toe die Joego-Slawiese weermag ook 'n offensief teen die Kosovo-Bevrydingsleër (KBL) van stapel gestuur het. Dit het groot ontwrigting in die gebied veroorsaak en 'n geskatte 400000 Albanese tydelik ontheem.

Kyk R. Jeffrey Smith en William Drozdiak: "The anatomy of a purge" (Washington Post. 11.4.1999); Barton Gellman: "Slaughter in Racak changed Kosovo policy" (Washington Post, 18.4 1999); Elaine Sciolino en Ethan Bronner: "The road to war, a special report" (New York Times, 18.4.1999); John Kifner: "Horror by design, how Serb force purged one million Albanians" (New York Times. 29.5.1999); Michael R. Gordon en Tom Shanker: "How Yúgoslav military planned and mounted Kosovo's ravaging" (New' York Times, 29.5.1999). 
Dié veldtog is beëindig deur internasionale ingryping. Navo het Richard Holbrooke, die man wat Milosevic in 1995 sover gekry het om Bosnië prys te gee, na Belgrado gestuur om hom met lugaanvalle te dreig. Milosevic het, al was dit onwillig, toegegee en beloof om sy magte in Kosovo te verminder en 1800 lig bewapende internasionale waarnemers in Kosovo toe te laat.

Dit was agteraf gesien as waarskynlik slegs 'n rookskerm, want kort daarna was daar tekens dat die Joego-Slawe nie hul beloftes nakom nie. Maar in Washington het dit groot verligting veroorsaak en die fatale persepsie is gevestig dat Milosevic niks meer as 'n grootbek was nie, wat met die blote bedreiging van lugaanvalle hokgeslaan kon word. ${ }^{4}$

Veral die Amerikaanse minister van buitelandse sake, Madeleine Albright, is sterk daardeur beïnvloed. Haar houding is sterk deur haar eie persoonlike agtergrond bepaal. Sy is in die jare dertig in die destydse Tsjeggo-Slowakye gebore as kind van Joodse ouers (haar Joodse identiteit is iets waarvan sy pas in 1998 bewus geword het). Die feit dat die “appeasement"-beleid van Brittanje en Frankryk teenoor Nazi-Duitsland in 1938-'39 verantwoordelik was vir die oorgawe van haar geboorteland aan Adolf Hitler, was strykdeur 'n beslissende leitmotiv in haar houding teenoor die diktator Milosevic. Sy het uit die Tsjeggo-Slowaakse geskiedenis geleer het, dat diktators betyds gekeer moet word, en dat dit slegs deur harde maatreëls kon gebeur. Gevolglik, skryf Time, "she urged intervention in Kosovo without worrying too much about either the geostrategic ramifications (how it would affect Russia, China, Macedonia, Greece, et al.) or about game planning all the contingencies (how to cope with a horrific tide of refugees and be ready to use ground troops if Milosevic was defiant)". 5

Dit was inderdaad wat haar gedurende die Rambouillet-konferensie van Maart 1999 gedryf het. Dit sou ons te ver voer om uitvoerig op dié konferensie in te gaan; dis voldoende om te vermeld dat Milosevic (wat in Belgrado agtergebly het) gekonfronteer is met die eis dat Kosovo se outonomie herstel moes word, dat die Joego-Slawiese weermag alle operasies in die gebied moes staak, dat slegs 5000 Joego-Slawiese soldate in die gebied mog bly, en dat die inwoners binne drie jaar in 'n referendum oor afskeiding van die Joego-Slawiese federasie getoets sou word.

Dit is duidelik dat Navo - en dan veral die Amerikaners - Milosevic diep met hul arrogansie gekwets het. Trouens, niemand minder nie as Henry Kissinger, dalk die invloedrykste kritikus van Navo se strategie, het oor Rambouillet gesê dat dit 'n "provocation" was; "an excuse to start bombing.". "Rambouillet is not a document that an angelic Serb could have accepted. It was a terrible diplomatic document that should never have been presented in that form."

4 Elaine Sciolino en Ethan Bronner: "The politics: no will for troops on eve of election" (New York Times, 18.4.1999).

5 Walter Isaacson: "Madeleine's War" (Time, 17.5.1999).

6 Boris Johnson: "Cold War warrior scorns 'new morality"' (Daily Telegraph, 28.6.1999). 
Hoe ook al, die mislukking van Rambouillet was vir Milosevic waarskynlik slegs die laaste strooi om Operasie Hoefyster, waarvan die beplanning al klaar voltooi was, aan die gang te kry. Dieselfde nag dat die eerste lugaanvalle uitgevoer is, 24 op 25 Maart, het die eerste Joego-Slawiese militêre en paramilitêre eenhede - uiteindelik sowat 40000 man, gerugsteun deur 300 tenks en 150 kanonne-Kosovo binnegerol.

Die Joego-Slawiese metodes, blykens dokumente wat ná die besetting van Kosovo deur Navo-troepe ontdek is, is ruimskoots vantevore fyn beplan. Een van Navo se inligtingsoffisiere wat die dokumente onder oë gehad het, het dit só opgesom: "We now realise that this wasn't mad dog killing. They mapped out which towns and villages they wanted to cleanse as a priority, and the killings started there. It was organised from the top, and the plan went like clockwork."

Die patroon was min of meer só: troepe het 'n etnies-Albanese dorpie binnegeval, wild en wakker 'n paar skote geskiet en alle mense uit hul huise gedwing. Pour encourager les autres, om die res te intimideer, is enkeles wat traag of opstandig gelyk het, doodgeskiet en 'n paar vroue verkrag. Die identiteitsdokumente van die oorgeblewenes is dan afgeneem en hulle is aangesê om in die pad te val na Albanië of Macedonië, wat ook al die naaste was. Sommige het ook na Montenegro ontvlug. Ná die oorlog is vasgestel dat enkele honderde mense so vermoor is, maar daar was klaarblyklik geen georganiseerde volksmoord nie; die doel was eenvoudig intimidasie om die mense weg te dryf. Verkragtings het wel op groot skaal voorgekom. ${ }^{8}$

Uit die Joego-Slawe se optrede blyk drie basiese strategiese doelstellings. Die eerste was om die KBL en sy guerrilla-ocrlog 'n nekslag toe te dien. Dit was Mao Zedong wat op die deurslaggewende belang van die plaaslike bevolking (PB) vir enige guerrilla-oorlog gewys het: net soos 'n vis nie sorrder water kan oorleef nie, is die steun van die PB vir die guerrilla onontbeerlik. ${ }^{9}$ Die Joege-Slawe het dit anders aangevoor: hulle het die PB massaal uit die land probeer dryf. In die proses is, volgens die VN se Konferensie oor Menseregte, sowat 860000 mense oor die grense verdryf en nog sowat 400000 binne Kosovo self ontheem. $^{10}$

Ten tweede was die doel om Kosovo van soveel moontlik Albanese te suiwer. Daarom ook is die vlugtelinge se identiteitsdokumente afgeneem, sodat hulle nie later kon bewys dat hulle inderdaad Kosovare was nie.

7 John Sweeney: "Seized Serb ducuments link Milosevic to mass killings" (The Observer,., 27.6.1999).

8 Kyk bv. R. Jeffrey Smith en William Drozdiak: "The anatomy of a Purge" (Washington Post,, 11.4.1999); R. Jeffrey Smith: "New refugees tell of stepped-up Atrocities" (Washington Post, 15.4.1999); Peter Finn en R. Jeffrey Smith: "Sudden death in Kosovo's 'Heart of Darkness"” (Washington Post, 30.4.199); John Kifner: "How Serb forces purged one million Albanians" (New York Times, 29.5.1999); Michael R. Gordón en Tom Shanker: "How Yugoslav military personnel planned and mounted Kosovo's ravaging" (New York Times, 29.5.1999).

9 Geoffrey Fairbaim: Revolutionary Guerrilla Warfare. The Countryside Version (Middlesex, Pebguin Books, 1974). p. 99.

10. Frankfurter Rundschau. 12.6.1999. 
Die derde oogmerk was klaarblyklik 'n strategiese teenoffensief teen Navo. Deur die toevloed van soveel honderdduisende vlugtelinge na veral Albanië en Macedonië is nie slegs dié twee lande ernstig gedestabiliseer nie, maar is die Navo-magte wat daar gereed gestaan het om ingevolge die Rambouilletplan die voorhoede van 'n vredesoperasic in Kosovo te wees (en wat selfs die kern van 'n werklike invalsmag kon word) gedwing om al hul energie aan dié probleem te wy. Só is dié potensiële bedreiging geneutraliseer nog voordat dit 'n gevaar kon word.

Feit is dat die Joego-Slawiese weermag nie op gelyke vlak met Navo kragte kon meet nie. Vir eers was Navo veel sterker, maar Navo (veral Amerika) se sterk punt het veral op die gebied van sy hoë tegnologie gelê. As Joego-Slawië Navo op sy eie terrein tegemoet probeer tree het, sou die oorlog, menslik gesproke, waarskynlik binne enkele dae verby gewees het. Hulle het dus náás die lugoorlog 'n tweede veldtog op die grond in Kosovo van stapel laat loop, die proses van etniese suiwering. Daarteen kon die Navo-vliegtuie, hoe hard hulle ook al probeer het, nie veel hond haaraf maak nie.

Die Amerikaanse militêre teoretikus Robert Leonhard se konsep van "dislocation" kan help verduidelik waarom die Joego-Slawiese reaksie - hoe bedenklik dit ook al moreel was - militer slim was. "Dislocation is the art of rendering the enemy's strength irrelevant," skryf Leonhard. "Instead of having to fight or confront the hostile force on its terms, the friendly force avoids any combat in which the enemy can bring his might to bear." Hy onderskei twee vorms van "dislocation", te wete "positional and functional dislocation".

Eersgenoemde is vir ons doeleindes irrelevant; dit gaan bloot oor misleiding van die vyand en verwante sake. Die tweede is wel belangrik, en hier gebruik hy die geveg tussen Dawid en Goliat om dit te verduidelik. Goliat was baie sterker, beter bewapen en beter opgelei as Dawid, maar uiteindelik het dit geen invloed op die uitslag gehad nie. Dawid het sy teenstander nie toegelaat om sy sterk punte aan te wend nie deur hom van ' $n$ afstand met sy slinger tussen die oë te tref en uit te skakel. Dié en ander voorbeelde uit die krygsgeskiedenis "show the effectiveness of employing technology and tactics to functionally dislocate the enemy's strength. As maneuver theory absolutely demands the avoidance of enemy strength, the commander who tends to fight along these lines must think in terms of dislocation rather than facing such strength."

Omdat nie veel bekend is van hoe Milosevic se denke deur die oorlog ontwikkel het nie, is dit moeilik om veel oor sy verdere strategie te sê. Sy doel was blykbaar enersyds om uit te hou en te hoop dat die verdeeldheid in Navo groot genoeg vir 'n skeuring word, en andersyds dat Rusland, sy groot bondgenoot, hom diplomatiek en andersins te hulp sou snel. Toe Armando Cossuta, hoof van die Italiaanse Kommunistiese Party, Milosevic kort ná die aanvang van die gevegte vra wat sy doel in hemelsnaam was, was sy antwoord: "Dit sal 'n tragedie wees, maar dit gaan die graf van Navo wees. Dié oorlog word die einde van Navo."12

1 Robert Leonhard: The Art of Maneuver. Maneuver-Warfare Theory and AirLand Battle (Novato, Presidio, 1991), pp. 66-67 en 73.

12 Andreas Englisch: "Der Krieg is das Grab der Nato" (Die Welt, 19.4.1999). 
En ofskoon hy volgens Aleksa Djilas geen voorliefde vir die Russe had nie ${ }^{13}$, het hy in 'n onderhoud met die Slowaakse vakbondkoerant Praca uitdruklik gesê: "Ons verwag natuurlik dat Rusland ons sal help," en spesifiek verwys na "militêre en tegniese hulp".14 Uiteindelik was Milosevic se hoop op Rusland vergeefs. Ondanks sy diepe gegriefdheid oor Navo se eensydige optrede en die feit dat hy nie van die begin af by die operasies teen JoegoSlawië betrek is nie, het Moskou nie die verwagte steun aan Belgrado verskaf nie.

Navo se politieke doelstellings: Dis duidelik dat Navo die Joego-Slawiese leier totaal verkeerd beoordeel het. Arrogansie en selfoorskatting het 'n groot rol gespeel: "[T]here was the vaguely racist belief," het Jonathan Eyal van die Royal United Services Institute in Londen oor die BBC gesê, "that the 'little people' in the Balkans are no match for Nato air power: drop a few bombs on these 'natives' in Yugoslavia and they will sue for peace. The idea that Milosevic would simply refuse to compromise and absorb the air strikes was not seriously considered." 15

Dat hy nie heeltemal verkeerd was nie, blyk uit dié verduideliking van 'n senior Amerikaanse amptenaar: "As we contemplated the use of force over the past 14 months, we constructed four different models. One was that the whiff of gunpowder, just the threat of force, would make Milosevic step down. [Dit is wat die vorige Oktober gebeur het.] Another was that he needed to take some hit to justify acquiescence. Another was that he was a playground bully who would fight but back off after a punch in the nose. And the fourth was that he would react like Saddam Hussein."

Dié modelle is in interne debatte nogal taamlik rondgegooi, maar volgens die amptenaar is die "Saddam-model" - die een wat ten slotte werklikheid geword het - as die onwaarskynlikste beskou. Madeleine Albright se uiteindelike voorkeur is gegee aan die "skoolboelie-model", en die verwagting was dus dat hy ná slegs enkele dae bes sou gee. ${ }^{16}$ Dis waarom die lugaanvalle aanvanklik so eina was. Dis waarom Albright op aand van 25 Maart, die eerste dag van die Navo-operasie, op beeldradio verklaar het: "I don't see this as a longterm operation. I think this is something, the deter and damage, is something that is achievable within a relatively short period of time." Slegs elf dae later was sy weer op TV. Toe was haar deuntjie anders: "We never expected this to be over quickly. The president himself has said: "This is not a 3-second commercial',",17

Uit pres. Bill Clinton se aanvanklike openbare uitlatings kan afgelei word dat Milosevic se onverwags felle mi'itêre reaksie in Kosovo, Navo se oorlogsdoel taamlik deurmekaargekrap het. Kort ná dic begin van die bombardemente het hy Milosevic - dalk onder invloed van Albright - met Adolf Hitler vergelyk en te kenne gegee dat die Europese stabiliteit in die gevaar kon kom as hy nie gestuit word nie. "We also act to prevent a wider war," het hy gesê, en daarop gewys dat ofskoon Kosovo klein is, "it sits at the dividing line of

13 Nuusberig van Sapa-AFP, 21.4.1999, soos uitgestuur aan die pers.

14 Nuusberig van Sapa-AFP, 20.4.1999, soos uitgestuur aan die pers.

15 Jonathan Eyal: Analysis: Is Nato winning?, 13.4 .1999 (http://bbc.co.uk).

16 Thomas W. Lippman: "State dept. miscalculated on Kosovo" (Washington Post, 7.4.1999).

17 John F. Harris: "Reassuring rhetoric conflicts with reality" (Washington Post, 8.4.1999). 
Europe, Asia and the Middle East, the dividing line between Islam and Christianity, close to our Turkish and Greek allies to the south, our new allies Hungary, Poland and the Czech Republic to the north, surrounded by small and struggling democracies that easily could be overwhelmed the flood of refugees Mr. Milosevic is creating ... If we were to do nothing, eventually our allies and then the United States would be drawn into a larger conflict, at far greater risks to our people and far greater costs."

Dit was natuurlik absurd. Wat in die Balkan gebeur, trek weliswaar die aandag van die Europese lande sterk, maar dit het geen invloed - altans nie in dié stadium - op die Europese stabiliteit en veiligheid nie. In 1914 was dit met die uitbreek van die Eerste Wêreldoorlog wel die geval, maar slegs omdat die Balkan die toneel was van gebiedsaansprake en -ambisies van twee groot moondhede, Oostenryk-Hongarye en Rusland, wat albei bowendien met ' $n$ ingewikkelde stelsel van bondgenootskappe aan ander groot moondhede gekoppel was. Só kon die moord op die Oostenryks-Hongaarse troonopvolger, aartshertog Franz Ferdinand, in Sarajevo op 28 Junie 1914 deur 'n Serwiese student - iets wat in beginsel ' $n$ bilaterale saak tussen Oostenryk-Hongarye en Serwië kon gebly het - die vonk in 'n veel groter kruitvat word. Geeneen van dié faktore was in 1999 aanwesig nie; dit was 'n suiwer interne konflik tussen die federale Joego-Slawiese regering en die etnies-Albanese Kosovare. Selfs die diplomatieke betrokkenheid van Rusland aan die kant van sy historiese bondgenote, die Serwiërs, het weens Rusland se ekonomiese en militêre swakhede, op kort en selfs middellang termyn geen gevaar vir "a wider war" ingehou nie.

Ook kon Milosvic, al was hy moreel duidelik die "bad guy", verreweg nie met Hitler vergelyk word nie. Hitler het nie alleen miljoene mense koudbloedig laat vermoor nie; in Duitsland het hy 'n kragtige instrument gehad wat hom byna-byna sy doelstellings laat bereik het. Milosevic se bloedvergieting, laakbaar soos dit was, was nie naastenby in dieselfde klas nie, en Joego-Slawië (sekerlik ná die uiteenval van die oorspronklike federasie in 1991-'92) kan kwalik as iets meer as 'n derderangse Europese moondheid beskryf word.

'n Paar dae later het Clinton vir die eerste keer drie onmiddellike doelwitte geïdentifiseer: Die Joego-Slawiese gewapende magte moet Kosovo verlaat; die ontheemde Kosovare moet toegelaat word om terug te keer; en 'n internasionale veiligheidsmag moet op die been gebring word om die Kosovare te beskerm terwyl hulle na selfregering ontwikkel. Dit was 'n duidelike radikalisering in die oorlogsdoel, meegebring deur die vinnige ontwikkeling van die militêre situasie. ${ }^{19}$

Einde April het Navo se strategie op sy jaarlikse spitsberaad in Washington - wat eintlik ' $n$ feestelike geleentheid weens sy vyftigjarige bestaan moes wees - 'n beslissende radikalisering ondergaan. Blair het die rigting reeds enkele dae dae vantevore met openbare uitsprake begin aandui. "We are fighting for a world where dictators are no longer able to visit horrific punishments on their own peoples in order to stay in power," het hy in 'n artikel in Newsweek geskryf. En: "We need to enter a new millennium where dictators know that they cannot get away with ethnic cleansing or repress their peoples with impunity. In this conflict

18 "Clinton's speech on Kosovo: 'We also act to prevent a wider war"' (New York Times, 2.4.1999).

19 “A moral imperative: Excerpts from Clinton's adress" (Washington Post, 16.4.1999). 
we are fighting not for territory but for values. For a new internationalism where the brutal repression of whole ethnic groups will no longer be tolerated. For a world where those responsible for such crimes have nowhere to hide. ${ }^{20}$

'n Paar dae later het hy in Chicago in 'n rigtinggewende beleidstoespraak verder op die tema voortgeborduur toe hy te kenne gegee het dat menseregte voortaan 'n belangrike faktor sou wees by besluite oor oorlog en vrede. Sake soos volksmoord, het hy gesê, "can never be a purely internal matter". "We are all internationalists now," lui die beslissende deel van sy toespraak met die titel Doctrine of the International Community, "whether we like it or not. We cannot refuse to participate in global markets if we want to prosper, we cannot ignore new political ideas in other countries if we want to innovate, and we cannot turn our backs on conflicts and the violation of human rights within other countries if we want still to be secure." Hy het daarop gesinspeel dat Navo se nuwe rol kon word om die militêre instrument van 'n nuwe morele wêreldorde te wees, eerder as 'n suiwer verdedigende bondgenootskap. "If we can establish and spread the values of liberty, the rule of law, human rights and an open society then that is in our interest too. The spread of our values makes us safer. As John Kennedy put it: 'Freedom is indivisible and when one man is enslaved, who is free?'" Dus, het Blair gesê, "the principle of non-interference must be qualified ...,"21

Die menseregte-houding is oorgeneem in die finale communique van die spitsberaad, ofskoon 'n mens die agtergrond moet ken as jy dit in die droë amptenaarstaal wil raaksien: "To stand ready, case-by-case and by consensus, to contribute to effective conflict prevention and to engage actively in crisis management, including crisis response operations.".22

Vir die internasionale politieke stelsel kan die ingrypende aard hiervan amper nie oordryf word nie. Ons sal later weer hierop terugkom, maar dis tog nodig om te wys op die feit dat die nugter Economist onmiddellik gewaarsku het: "The necessity is not so much to prove that this was a 'just cause' ... but to reassure a suspicious world that NATO has not given itself the right to attack sovereign nations at whim. However absurd that suspicion may seem to countries within NATO, it has taken hold in places as far apart as China, India and Latin America." ${ }^{23}$

Die Bergerdoktrine: Die praktiese wyse waarop dit alles rakende Kosovo in die praktyk gebring is, was 'n radikale afwyking van die Amerikaanse strategie in die Golfoorlog van 1990-'91. Op grond van die inkrementele wyse waarop Amerika in die jare sestig in Viëtnam betrokke geraak het, en die negatiewe operasionele uitwerking daarvan, het genl. Colin Powell, hoof van die Amerikaanse weermag, in 1989 die sogenaamde Powelldoktrine geformuleer. Met die vernedering van Viëtnam in sy agterkop het sy leer daarop neergekom dat Amerika baie sorgvuldig moes oorweeg by welke konflikte hy betrokke raak, sodat hy nie die gevaar loop om weer te verloor nie. Time het die Powelldoktrine só opgesom: "His doctrine had two tenets: first, the 'biggest s.o.b. on the block' rule, that America should enter

20 Tony Blair: "A new generation draws the line" (Newsweek, 19.4.1999).

${ }^{21}$ Hugo Gurdon: "Victory is only exit. says Blair". (Daily. Telegraph. 23.4.1999).

22 Kyk volledige verklaring op Navo-webtuiste (www nato int).

23 "Defining Nato's aims" (The Economist. 24.4.1999). 
fights with every bit of force available or not at all. Second, that the U.S. should never start a fight it didn't know how to end." ${ }^{24}$

Dit is nie hoe die oorlog in Kosovo aangepak is nie. Daar is die vlak van geweld geleidelik opgevoer, en bowendien het die besluit om die lugveldtog - anders as in die geval van Irak in 1991 - nie met 'n grondoffensief op te volg nie, afgewyk van Powell se vereiste dat daar met oorweldigende krag ingegryp moet word.

Die dryfkrag agter die verwerping van die Powelldoktrine was Clinton se nasionale veiligheidsraadgewer, Sandy Berger. In 'n koerantonderhoud het Berger gesê die Powelldoktrine kom daarop neer dat Amerika slegs by grootskaalse oorloë betrokke mag raak. "Where the Powell doctrine needs to be updated is on the question whether or not military force kan be used for more limited purposes than the decimation of the enemy. It cannot mean that we have no choices between nothing and everything. ${ }^{25}$ By 'n ander geleentheid het hy gese "there can be circumstances short of an existential threat to the United States where the use of force is appropriate". ${ }^{26}$

Gesien die feit dat Berger se benadering uiteindelik min of meer sukses behaal het, kan seker gestel word dat die Powelldoktrine deesdae vervang is deur die Bergerdoktrine. Dit is waarskynlik op grond hiervan dat pres. Clinton by verskeie geleenthede ná sy bewindsaanvaarding in 1992, missiel- en lugaanvalle op teikens in lande soos Irak, die Soedan en Afganistan laat doen het. Dit was aksies waarin geen enkele Amerikaner ooit sy lewe verloor het nie, en wat dus besonder aantreklik was vir 'n president wat self geen militêre agtergrond had nie en bowendien baie sterk deur meningspeilings gelei is.

Die probleem met al dié aksies was dat dit nooit werklik die gewenste uitwerking gehad het nie. Die aanval op die Soedan, het later geblyk, was op foutiewe inligting gebaseer en het wêreldwye verontwaardiging (nie slegs in die Moslemwêreld nie) uitgelok; die feit dat Afganistan die terroristeleier Osama bin-Laden uitgeskop het, het niks met Amerika se wense te make gehad nie, en die laaste reeks lugaanvalle op Irak het pres. Saddam Hoesein laat besluit om die $\mathrm{VN}$ se wapeninspekteurs vir goed toegang tot sy land te weier. Berger het natuurlik in teorie reg, maar die praktyk laat hom nie altyd maklik in 'n akademies-teoretiese keurslyf dwing nie.

Sy benadering was dan ook omstrede. Die gesamentlike stafhoofde van die Amerikaanse weermag, wat steeds ten gunste van die Powelldoktrine was, was dit nie daarmee eens nie. In gesprekke agter die skerms het hulle volgens inligting wat in die Amerikaanse pers uitgelek het, herhaaldelik hul onwilligheid uitgespreek om hoegenaamd militêr in die Balkan betrokke te raak. Hulle het diplomatieke metodes, sanksies of ander "sagte" middele voorgestaan, eerder as lugaanvalle - wat na hul mening sonder 'n aanvulling op die grond nie die gewenste uitwerking kon hê nie. En vir 'n grondaanval was hulle glad nie

24 Bruce W. Nelan: "Kosovo crisis: the mission" (Time, 5,4,1999).

25 John Harris: "Berger has shaped U.S. role in Balkans" (Washington Post, 16.5.1999).

26 Barton Gellman: "What the peace plan means" (Washington Post, 5.6.1999). 
lus nie. ${ }^{27}$ Maar uiteindelik was dit die politici wat die deurslag gegee het, en die militêre moes uiteraard daarby inval.

Rusland en China: Nog 'n saak wat op die strategiese vlak behandel moet word, is die buitengewoon felle wyse waarop Rusland en China op die ingryping in Kosovo en Navo se nuwe strategiese rigting gereageer het.

Die verlies van Rusland se cordon sanitaire (wat Josef Stalin teen dic einde van die Tweede Wêreldoorlog en onmiddellik daarna opgebou het) in Oos- en Sentraal-Europa in 1989 en die land se desintegrasie in vyftien afsonderlike state was vir die Russe, gewoond aan hul supermoondheidstatus, traumaties. Die feit dat Navo teen Serwië ingegryp het, sonder om Rusland te raadpleeg of sy historiese vriendskap met die gebied hoegenaamd in ag te neem, het die Russe diep gegrief en hul gedrag bepaal.

Op 9 April is die wêreld kortstondig skrikgemaak toe 'n nuusberig uit Moskou die wêreld ingestuur is met die nuus dat pres. Boris Jeltsin - volgens wat die voorsitter van die Russiese parlement, Gennadi Seleznjof, ná 'n gesprek met Jeltsin aan joernaliste gesê het opdrag gegee het dat die Russiese kernmissiele soos vroeër weer op Westerse stede gerig word. Dit is binne enkele ure ontken, maar later dieselfde dag het Jeltsin die Weste met 'n Derde Wêreldoorlog gedreig as Navo grondtroepe in Kosovo instuur. "Ek het vir Navo, die Amerikaners, die Duitsers gesê moenie ons in die rigting van militêre optrede dwing nie," was Jeltsin se woorde op die Russiese beeldradio. "Anders sal daar beslis 'n Europese oorlog wees, dalk selfs 'n wêreldoorlog." ${ }^{28}$ Die eintlike punt met die kernwapen-dreigement is gemaak met 'n verdere berig uit Moskou dat dit slegs sowat tien minute sou duur om die kernmissiele te herprogrammeer om teen die Weste gerig te word. ${ }^{29}$ Die boodskap was baie duidelik: Rusland beskou homself steeds as 'n groot moondheid; moet hom nie uittart deur hom te negeer nie!

Die skok in die Weste was inderdaad groot, veral in 'n land soos Duitsland, wie se geopolitieke posisie in die sentrum van Europa histories goeie betrekkinge met die kolos in die Ooste gedikteer het. Lees 'n mens Navo-leiers se openbare uitsprake in dié tyd, val 'n hele koor op wat opeens sê Rusland is 'n belangrike rolspeler en moet by 'n oplossing vir die geskil betrek word.

Nietemin bly die feit staan dat die Russe die Weste nie sodanig kon intimideer dat die aanslag op Joego-Slawië gestaak word nie. Daar is wel 'n antwoord, wat lê in Rusland se ekonomiese en veral militêre inploffing sedert die desintegrasie van die Sowjet-Unie einde 1991. Genl. (afg.) Wladimir Beloes, deesdae 'n militêre ontleder in Rusland, se antwoord lui só: "The Yugoslav events have shown that we were little reckoned with, and we failed to stop this aggression despite all our efforts. The Soviet Union would have been able to do this. But Russia found it was beyond our strength. We live in a world of military strength." Voorts, sê

27 Bradley Graham: "Joint chiefs doubted air strategy" (Washington Post, 5.4.1999).

28 Nuusberigte van Sapa-AP en Sapa-AFP, 9.4.1999. soos uitgestuur aan die pers; Celestine Bohlen: "Russia clarifies position on NATO bombing of Yugoslavia (New: York Times, 10.4.1999).

29 Nuusberig van Sapa-AP. 12.4.1999, soos uitgestuur aan die pers. 
'n hooggeplaaste anonieme Russiese bron, het Rusland weens sy ekonomiese agteruitgang nie bygebly in die militêr-tegtnologiese wedloop nie. "Russia has slept through the preparation stage of the war. At the present, Russia's armed forces do not posess an arsenal of high precision weapons. This war demonstrated Russia's unpreparedness for this type of war."

Die gevolg hiervan was ewenwel dat 'n enorme vlaag anti-Westerse nasionalisme hom van die Russe meester gemaak het. In 'n landwye meningspeiling is bevind dat slegs $39 \%$ van die Russe positief teenoor Amerika was, teenoor $67 \%$ slegs drie maande vantevore. Die persentasie wat gesê het hul persepsie van Amerika is "hoofsaaklik sleg" of "baie sleg" het van 23 tot $49 \%$ gestyg. $^{31}$

Andrew Harding, die BBC se korrespondent in Moskou, het 'n ontmoeting met 'n groep Russiese studente onder meer só beskryf: "[P] eople spoke angrily and passionately about how they felt let down by the West - as if a marriage were breaking up. 'We looked up to you,' said one woman in flawlesss English. 'But not any more. This is your New World Order: America does wat it wants. To you we're just a poor, crazy country.' 'This is Russia's fate,' said another. 'Caught between East and West. We want to be like Europe - but Europe doesn't want us.' Harding voeg self by: "For a while, many Russians believe that they could anchor their country, hold it steady, through partnership with the West. But today that idea is going rapidly out of fashion."

Uiteindelik het Rusland in die persoon van Jeltsin se persoonlike afgesant (en vroeëre premier), Wladimir Tsjernomirdin, 'n deurslaggewende rol gespeel om Milosevic laat toegee. Maar alles dui daarop dat die skade in die betrekkinge tussen Rusland en die Weste onherstelbaar beskadig kan wees.

Wat China betref, het dié land se betrekkinge met veral Amerika sedert die Tiananmen-slagting van April 1989, nog nooit werklik heeltemal herstel nie. Washington se toestemming in 1995 dat pres. Li Teng-Hwi van Taiwan die land privaat mog besoek, het China buitengewoon boos laat reageer. Bowendien was die wyse waarop die Amerikaners in 1996, toe die Chinese Taiwan met missiel-oefeninge in sy omgewing probeer intimideer het, heel doelbewus twee vliegdekskip-taakmagte deur die Straat van Taiwan laat vaar het, vir Beijing uiters vernederend omdat dit die Amerikaanse oppermagtigheid selfs langs die Chinese kus bewys het. 'n Kortstondige oplewing in die betrekkinge het gesorg vir staatsbesoeke oor en weer deur Clinton en pres. Jiang Zemin, maar reeds voor die Kosovokrisis het dié effense toenadering al weer getaan.

Toe Amerikaanse bomme die Chinese ambassade in Belgrado dus in die nag van 4 op 5 Mei met die verlies van drie menselewens tref - klaarblyklik ' $n$ fout van die Amerikaanse militêre inligtingsdiens ${ }^{33}$ - was die gort gaar. Die Chinese het alle verduidelikings en

30 Ibid.

31 Michael Wines: "Hostility to U.S. is now popular in Moscow" (New York Times, 12.4.1999).

32 Andrew Harding: "Russians feel Kosovo fall-out", 13.4.1999 (www.bbc.co.uk).

33 Eric Schmitt: "Aim, not arms, at the root of mistaken strike on embassy" (New York Times, 10.5.1999). 
verskonings verwerp en (dalk omdat dit hulle polities gepas het?) volgehou dat dit met opset gedoen was. Twee weke lank het die Chinese diktatuur, wat andersins hard teen openbare betogings optree wat hy nie self georganiseer het nie, dadeloos toegekyk hoe 'n histeriese horde betogers anti-Amerikaanse slagspreuke skreeu, Amerikaanse vlae verbrand, die Amerikaanse ambassade in Beijing en konsulate elders onder die klippe steek, en selfs blankes wat dalk Amerikaners kon wees op straat aanrand. Dit was 'n spontane uitbarsting van felle Chinese nasionalisme, een wat die diktatuur die idee kon gegee het om sy wankelrige posisie binnenslands te verstewig deur sake vir Amerika so moeilik moontlik te mak. Wat dit alles vir die breër internasionale politiek kan inhou, kom later aan die orde.

Koalisie-oorlogvoering: Eenheid van bevel is, so leer die militêre teorie, buitengewoon belangrik. Troepe in die veld moet hul bevele van één bevelvoerder of hoofkwartier kry wat met één stem praat, nie met 'n kakofonie stemme nie. Op operasionele en taktiese vlak kan dit meestal betreklik maklik gedoen word. Die probleem is dat wanneer 'n koalisie soewereine state bymekaar kom om oorlog te voer, die strategiese leiding alte dikwels ' $n$ kompromis is - en dus vaag of selfs teenstrydig.

In dié geval bestaan Navo uit nie minder nie as negentien lidlande, elk met eie nasionale belange wat nie altyd identies aan dié van 'n ander is nie, elk met 'n eie regering wat na sy politieke belange kyk, elk met 'n eie politieke kultuur en manier van dinge doen. Naas die doel van 'n militêre oorwinning oor Joego-Slawië was die tweede gebod wat daarmee gelykstaan dus die noodsaak om 'n skeuring in dié uiteenlopende bondgenootskap te keer. Aangesien Navo met die konsensus-beginsel werk, had elkeen van die negentien lidlande immers 'n vetoreg waarmee die hele operasie gekelder kon word. Die ander sy van die munt was natuurlik dat dit 'n skeuring in die bondgenootskap sou beteken, waartoe niemand bereid was nie.

Feit is dat die buitelandse beleid van enige moderne staat - dit geld veral vir demokrasieë, maar ook outoritêre regimes en diktature moet daarmee rekening hou - mede deur sy binnelandse politiek bepaal word. So was Griekeland, wie se bevolking om godsdienspolitieke redes fel pro-Serwies is (hulle is almal lid van Ortodokse kerke), van die begin af heeltemal teen die oorlog gekant. ${ }^{34}$ Tog het die land nie sover gegaan as om die operasie as sodanig te veto nie. Italië (wie se nabye geografiese ligging vlak oorkant die Adriatiese See onontbeerlik vir die voer van die lugaanvalle was) het ernstige bedenkinge gehad, hoofsaaklik omdat die regerende koalisie kwaai verdeeld was. ${ }^{35}$ Hongarye, met sy oë angstig op die groot Hongaarse minderheid in die Serwiese provinsie Voivodina gerig, het styf duim vasgehou dat niks meer as 'n logistieke bydrae van hom verlang word nie. ${ }^{36}$ Duitsland, wat kwalik ses maande tevore 'n nuwe koalisie, bestaande uit die SosiaalDemokratiese Party en die tradisioneel pasifistiese Groenes gekry het, kon met moeite voldoende binnelandse konsensus vir lugaanvalle - sy eerste buitelandse militêre

34 Helena Smith: "Angry Greeks hit Nato supply lines" (The Guardian, 30.4.1999).

35 Ian Traynor en John Hooper: "Germany, Italy say a flat no to ground troops" (The Guardian,, 19.5.1999); Loyal Italians" (The Economist, 17.4.1999).

36 Nuusberig van Sapa-AP, 21.4.1999, soos uitgestuur aan die pers; "Nervous Hungarians" (The Economist, 24.4.1999. 
oorlogsoperasie sedert 1945 - kry, maar Bondskanselier Schröder het ronduit 'n grondoffensief geveto. Só iets sou die prekêre konsensus ruimskoots verbreek en sy kabinet tot 'n val bring. ${ }^{37}$

Brittanje se premier, Tony Blair, het opgetree asof hy bitter graag die moderne Winston Churchill wou wees, en het dus kwaai vir die grondoffensief-opsie geagiteer.

Clinton self het nog geworstel met die naweë van die Monica Lewinsky-affêre en kon ook geen voldoende konsensus met die Republikeins-oorheerste Kongres bereik nie. Clinton was by uitstek 'n politikus met, soos die Amerikaanse politikoloog Dmitri Simes dit gestel het, die een oog voortdurend op meningspeilings en koerantopskrifte. ${ }^{38}$ In sy geval was die Amerikaanse publiek nooit werklik oortuig van die noodsaak van die oorlog nie en namate die konflik met al sy rukke en stote gevorder het, het die steun beduidend afgeneem, terwyl die steun vir 'n moontlike grondoffensief nog aansienlik laer was, 'n feit wat Clinton se teenkanting teen 'n grondoffensief minstens gedeeltelik bepaal het. ${ }^{39}$

Waar die debat oor 'n grondoffensief effens later behandel word, moet dié politieke beperkings op Navo se operasionele vryheid deeglik in ag geneem word. Op die keper beskou, het Navo dus uiteindelik die maksimum gedoen wat sy interne verdeeldheid en binnelandse politieke probleme hom toegelaat het, en die minimum wat nodig was om Milosevic te oorwin.

Die media-oorlog: In alle moderne demokrasieë (en selfs in outoritêre state) kan 'n regering nie meer soos vroeër na willekeur oorlog verklaar en vrede maak nie; daarvoor benodig hulle die steun - of op die allerminste die passiewe aanvaarding - van die bevolking. Waarskynlik die belangrikste instrument hiervoor is die nuusmedia - die gedrukte pers, radio en beeldradio, en deesdae selfs die Internet. Omdat die media in demokratiese state egter onafhanklik is, moet die regering en die militêre weet hoe om daarmee om te gaan, iets wat vir geharde soldate dikwels problematies is. Nietemin is die onafhanklikheid van die media juis 'n voordeel, want in die meeste gemeenskappe bevorder dié onafhanklikheid die media se geloofwaardigheid. $^{40}$

In die meeste Navo-lande het verskeie konflikte - veral die Falkland-oorlog (1982) en die Golfoorlog (1990-'91) - dit moeisaam by die militêre tuisgebring hoe belangrik die media is, en hoe elke bevelvoerende offisier die hantering van die media as ' $n$ integrerende deel van sy strategie moet beskou. In die Kosovo-oorlog is dié lesse, altans in die begin, skromelik oorboord gegooi.

37 Vgl. Christiane Schlötzer en Hans-Jörg Heims: "Wachsende Zweifel in der Bundesregierung am Nato-Einsatz" (Süddeutsche Zeitung, 5.5.1999). Nuusberig van Sapa-AFP, 3.4.1999, soos uitgestuur aan die pers.

John M. Broder: "Laurels elude president as public judges a war" (New York Times, 22.6.1999). Militaria, pp 236-251). 
Die problematiese aanvang van die oorlog, die feit dat Milosevic teen alle verwagtinge nie onmiddellik oorgegee het nie, het ook die hantering van die media sterk negatief beïnvloed. Die Amerikaanse joernalis Jason DeParle het dit só beskryf: "After 12 days of allied air attacks against Yugoslavia, military experts say the lack of detailed afteraction reports - routinely provided in past conflicts - have made it impossible to asess the allies' claim that they are steadily dismantling Belgrade's war-making powers.

"In briefings at the Pentagon and at NATO headquarters in Brussels, senior officials have refused to say exactly how many attack missions have been launched; how many of those missions have been completed despite the bad weather; how many bombs have been dropped; or what, precisely, the bombs have hit."

"Such statistical summaries were provided on a near-daily basis in the 1991 Persian Gulf War, even under an information policy then criticized by journalists as overly restrictive. In briefings over the past 12 days, allied officials have instead used vague charactarizations of progress, saying, for instance, that they are 'degrading and disrupting' the Yugoslav forces and having 'a debilitating effect on their ability to operate'."

Volgens DeParle het Kenneth Bacon, woordvoerder van die Pentagon, toegegee dat "we are taking a more conservative approach than in the past" om die veiligheid van die Navo-magte te beskerm: "We know the Serbs are watching us closely. We are saying as little as possible that could be used in defending against our sorties." Bacon het voorts gesê William Cohen, minister van verdediging, en genl. Hugh Shelton, hoof van die Amerikaanse weermag, meen die Pentagon is te vrygewig met die bekendmaking van inligting. "Frankly, general Shelton and secretary Cohen think we need to change the culture of the Pentagon, and make people more alert to the dangers that can flow from begin too generous - or you could say profligate or lax - with operational details." Genl. Clark het ook gewys op die aanwesigheid van drie Serwiese joernaliste, twee van dagblaaie en een van 'n nuusagentskap, wat die inligtingsessies in Brussel daagliks bygewoon het. ${ }^{41}$

In die mediawêreld was dit egter 'n omstrede benadering. Tereg het die New York Times in 'n hoofartikel verklaar: "When democracies send their military forces into combat, citizens need to know as much about the battles as sensible security precautions permit. In the case of Kosovo, with Western reporters barred by Serbia from covering the conflict on the ground, NATO and the Pentagon must provide a detailed account of the effectiveness of the air war. It is a responsibility they have so far largely failed to meei ... The chokehold on information fuels suspicions that NATO has withheld more detailed reports to shield itself from criticism that it failed to prepare a more intensive iinitial attack.

"In the weeks ahead, President Clinton may seek public support for escalating the air war, or even introducing ground troops into combat. Complicated political and security issues will have to be resolved before the conflict ends. It is essential that citizens have all the information they need to make informed judgments as these matters arise. Mr. Clinton and his

41 Jason DeParle: "Allies progress remains unclear as few details are made public" (New York Times, 5.4.1999). 
counterparts in Europe do themselves and their countries a disservice by so tightly controlling information about the battle in Kosovo. ${ }^{42}$

Nie slegs die media het kritiek op Navo se openbare skakeling gehad nie; ook oudmilitêre het dit gedeel. Die afgetrede Amerikaanse kol. John Warden (aft.), wat die lugveldtog teen Irak in 1991 help beplan het, het só gemeen: "In today's world, it seems there's information out there one way or another. You can't hide it. When you try to hide it, you create a bad impression, in this case raising significant doubts about strategy. ${ }^{.43}$

Tog lyk dit of dié kwaai bombardement kritiek ingang gevind het. Op 13 April het Clark die eerste omvattende inligtingsessie voor joernaliste in Brussel toegespreek. Na aanleiding daarvan het Pentagon-woordvoerder Kenneth Bacon verduidelik: "What you're seeing is both NATO and the Pentagon are becoming more open. Basically as we've become more comfortable with the operation, as we've realized what we can do and cannot do, we've been more forthcoming., 44

Op 18 April is eindelik berig dat Navo Alastair Campbell, perssekretaris van die Britse premier, gevra het om Navo se mediastrategie drasties te hervorm. Sy taak was onder meer om toe te sien dat die meeste inligting so gou moontlik op gesentraliseerde grondslag bekend gemaak word om te keer dat die gerugtemasjien meer geloofwaardigheid as Navo se bekendmakings kry en dat Navo met één stem praat, pleks van 'n kakofonie, soos tot in dié stadium die geval was. ${ }^{45}$

Hierna het sake aansienlik verbeter. Die storm kritiek het oorgewaai en alles dui daarop dat die goeie betrekkinge tussen die militêre en die media wat veral in die Golfoorlog opgebou is, herstel is. (Wat 'n mens jou natuurlik laat afvra: waarom moes die wiel weer van voor af uitgevind word?)

Alles in ag genome, het Navo uiteindelik die media-oorlog gewen. Die feit dat die bondgenootskap van sy aanvanklike foute geleer en soveel moontlik oop probeer wees het, het sy geloofwaardigheid aansienlik versterk. Daarteenoor was die Joego-Slawiese mediabenadering só duidelik propagandisties dat dit internasionaal geen geloofwaardigheid had nie, en selfs binnenslands met 'n sekere mate van skeptisisme betrag is. Dit alles bevestig eenvoudig vir die soveelste keer: in 'n moderne oorlogsituasie is die begrippe onafhanklikheid van die media, openheid en geloofwaardigheid absolute sinonieme. En sonder geloofwaardigheid kan die publiek se steun vir 'n oorlog blitsvinnig verdamp en die oorlogspoging self aansienlik ondermyn. Dis iets wat elke militêr deeglik moet besef en onder die knie kry, al val media-hantering ver buite sy ervarings- en opleidingsveld.

\footnotetext{
42 New York Times, 4.4.1999.

43 Nuusberig van Sapa-AP, 10.4.1999, soos uitgestuur aan die pers.

44 Philip Shenon: "Military starts giving detailed data on bombing" (New York Times, 14.4.1999).

45 Patrick Wintour: "Campbell set to spin for Nato" (The Observer, 18.4.1999).
} 


\section{DIE OORLOG OP OPERASIONELE VLAK}

Die debat oor lug vs. grond: Dié debat, wat op sowel politieke as militêre vlak intens gewoed het, is eintlik al ' $n$ baie ou een en het inderwaarheid al begin toe vliegtuie die eerste keer in oorlogvoering - in die Eerste Wêreldoorlog, 1914-'18 - gebruik is. Die debat het strykdeur basies dieselfde argumente gehad: diegene wat meen lugaanvalle is genoeg om 'n teenstander só te knak dat hy die stryd gewonne gee, en dié wat sê lugaanvalle moet met 'n grondoffensief opgevolg word.

Rondom Kosovo sou die debat weer losbars, maar dié keer is die besluitneming deur talle ander sake, hoofsaaklik politieke oorweginge, bepaal.

Reeds in Oktober 1998, toe die vorige krisis rondom Kosovo aan die gang was, het die Pentagon gekyk na watter tipe grondmag nodig sou wees om Joego-Slawië te verslaan. Die antwoord - dit was klaarblyklik meer 'n ingeligte raaiskoot as 'n werklik gefundeerde ondersoek - was 200000 man as die hele Joego-Slawië verslaan en beset moet word, en 75 000 man as dit slegs om die besetting van Kosovo gaan. Vir Clinton was dit hopeloos te veel en die idee is onmiddellik sonder verdere bespreking van die agenda afgehaal. ${ }^{46}$ Wat wel op die agenda geplaas is, ooreenkomstig die verwagting dat Milosevic betreklik maklik geïntimideer kon word, was beperkte lugaanvalle wat, indien nodig, geëskaleer kon word presies die soort benadering waarteen die militêre hulle verset het. ${ }^{47}$

Die gevolg is dat toe Operasie Allied Force eenmaal van stapel gestuur word, Clinton onmiddellik die grondaanval-opsie in die openbaar verwerp het. "The thing that bothers me about introducing ground troops into a hostile situation, into Kosovo and into the Balkans, is the prospect of never being able to get them out," het Clinton op beeldradio verklaar. ${ }^{48}$

Clinton moet uit sy agtergrond verstaan word. Hy was die eerste Amerikaanse president sedert Woodrow Wilson wat nooit uniform gedra het nie en die eerste van 'n nuwe geslag wie se denke nie deur sy ondervinding in die Tweede Wêreldoorlog gevorm is nie. In sy studentetyd, in die jare sewentig, was hy 'n diensplig-ontduiker en selferkende daggaroker (ofskoon hy, tot wêreldwye neerbuigende geamuseerdheid, ontken het dat hy ooit ingeasem het). Clinton het reg van die begin van sy eerste ampstermyn nooit gemaklik met die generaals omgegaan of ' $n$ gevoel vir die weermag as nasionale beleidsinstrument gehad nie. Die bestaan van hoë tegnologiese, super-akkurate wapens het sake vir hom makliker gemaak, want dit het hom in staat gestel om "bloedloos" (bloedloos aan Amerikaanse kant) geweld buite sy grense te gebruik. Dit was essensieel wat hom teen selfs die dreigement van 'n grondoffensief laat besluit het. 'n Ander man in die Wit Huis, een met groter begrip vir 'n weermag as politieke instrument, kon heel moontlik anders geoordeel het.

Die probleem met dié benadering was dat dit strategies onverstandig en polities dom was. Selfs al besluit 'n leier privaat om geen grondtroepe te gebruik nie, sê jy dit nie in die

\footnotetext{
46 John F. Harris: "Clinton saw no alternative to airstrikes" (Washington Post, 1.4.1999).

47 Bradley Graham: "Cohen wrestles with mission risks" (Washington Post, 11.4.1999).

${ }^{48}$ John F. Harris: "Clinton saw no alternative to airstrikes" (Washington Post, 11.4.1999).
} 
openbaar nie, want daardeur weet jou vyand dat 'n belangrike opsie van die tafel gehaal is en dit kan sy vasbeslotenheid om uit te hou slegs bevorder.

Die besluit het dan ook onder wye en skerp kritiek deurgeloop. Tipies van die kritici was die Britse nuustydskrif The Economist, wat in 'n hoofartikel geskryf het dat die verwerping van die grond-opsie 'n fout was. "A huge build-up of troops, able to fight in Kosovo, would not have been a commitment to use them, but would have provided the option - and created uncertainty in the enemy's mind. ${ }^{49}$ En die krygshistorikus Alistair Horne het daarop gewys dat "[a]t least the threat of it back in March would have wonderfully concentrated Milosevic's mind, saving much of the human and material wreckage that ensued". 50

Uiteindelik was slegs twee lande in beginsel ten gunste van die grondopsie, Frankryk en Brittanje. Eersgenoemde se houding was ook maar skynheilig, want die Franse het daarop gestaan dat 'n grondoffensief deur 'n resolusie van die Veiligheidsraad gemagtig moes word, iets wat hulle geweet het oombliklik deur die Russe en Chinese geveto sou word. ${ }^{51}$ Dit was dus weinig meer as 'n maatreël teen gesigsverlies.

Die Britte was anders: premier Tony Blair - ironies genoeg, aan die hoof van die eerste Britse kabinet dié eeu sonder 'n enkele minister met militêre ervaring - het hom as die groot pleitbesorger van die grond-opsie ontpop. In die dae voor die Navo-spitsberaad laat in April, het hy al hoe meer druk op die Wit Huis begin uitoefen om minstens nie die gebruik van grondtroepe uit te sluit nie. ${ }^{52}$

Die saak is die aand ná sy aankoms in Washington vir die spitsberaad by 'n private aandete met Clinton in die Wit Huis op die spits gedryf. Blair het dié aand blykbaar 'n omvattende pleidooi vir 'n grondoffensief gelewer. Clinton en Albright het aandagtig geluister; Berger was blykbaar nie onder die indruk nie. Uiteindelik het Clinton egter ernstig met Blair gepraat en hom daarvan oortuig dat die grondkwessie te verdelend vir Navo was om dit verder te voer. Hy het 'n beroep op die Brit gedoen om die saak nie by die spitsberaad te opper nie. In ruil daarvoor kon Blair dan die vyeblaar kry dat die grondopsie ten minste nie verwérp is nie; dat dit darem steeds op die agenda was. ${ }^{53}$

Clinton het sy sin gekry. Blair het die saak glo geen enkele keer op die spitsberaad geopper nie en Navo se eenheid is nie bedreig nie. Al wat dus gebeur het, is dat Javier Solana, sekretaris-generaal van Navo, die groen lig gekry het om die Pentagon se grondaanvalsplanne

49 "A bungled war" (The Economist, 8.5.1999).

so Alistair Horne: "Was the 'incompetent swatting from above the clouds' worth it?" (Sunday Argus, 20.6.1999).

51 Michael R. Gordon en Craig Whitney: "2 NATO allies press U.S. to weigh the use of ground forces" (New York Times, 22,4.1999).

52 George Jones en Ben Fenton: "Blair paves way for ground troops" (The Telegraph, 22.4.1999).

53 Ed Vulliamy en Patrick Wintour: "The Pentagon prepares" (The Observer, 25.4.1999); John F. Harris: "Clinton coaxes allies to fragile consensus" (Washington Post, 26.4.1999). 
van die vorige jaar op datum te laat bring. ${ }^{54}$ Maar dit het niks om die lyf gehad nie: "It was intended to box in ground troop talk before the summit," het 'n senior Amerikaanse amptenaar aan die Washington Post gesê. "We've been saying all along we have no intention of invading Yugoslavia, and we still don't.".55

Al waartoe Clinton uiteindelik bereid was, was die stuur van 24 Apacheaanvalshelikopters met sowat 3000 steuntroepe na Albanië. Maar ofskoon hulle ná 'n klomp vertragings uiteindelik in die loop van Mei gereed verklaar is, het Clinton uit vrees vir verliese en weens die bergagtige omgewing enduit toestemming weerhou om hulle operasioneel aan te wend. ${ }^{56}$

Teen die einde van die veldtog het die debat opnuut opgevlam, en weer was dit Tony Blair wat die aanslag gelei het, dié keer saam met genl. Wesley Clark in Brussel. Die argument was dat daar ten minste op baie kort termyn met die voorbereiding van 'n grondveldtog begin moes word; anders sou die veldtog nie voor die aanbreek van die winter in Oktober of November voltooi kon wees nie. ${ }^{57}$ Vir die eerste keer het Clinton, onder kwaai druk, toegegee dat 'n grondveldtog oorweeg kon word. Helfte Mei het hy dus die top-offisiere van sy weermag na hom ontbied om die saak te bespreek. Maar genl. Clark, die sterkste voorstander van die grond-opsie, is pertinent versoek om nié aanwesig te wees nie. "They don't want a vigorous presentation of what they know he will present and what he thinks is necessary to win," aldus 'n Wit Huis amptenaar ${ }^{58}$ - wat van die hele oefening 'n klug gemaak het en 'n mens laat dink dat dit nie ernstig bedoel was nie. Tog het Clinton teen begin Junie, volgens 'n latere rekonstruksie, op die punt gestaan om 'n grondoffensief goed te keur. ${ }^{59}$

Voordat die debat ewenwel verder kon ontwikkel, het Milosevic bes gegee en daarmee het die gedagtewisseling wat die oorlog betref irrelevant geword.

Die vraag is natuurlik of 'n grondoffensief in die lig van die politieke en militêre realiteite ooit werklik 'n praktiese opsie was. Polities is die antwoord nee. Soos reeds hierbo aangedui is, was Navo eenvoudig te verdeeld om tot iets meer as die lugveldtog in te stem. As Blair sy sin gekry het, sou Navo geskeur het. Alternatiewelik sou minstens die regerings van Duitsland, Italië en Griekeland waarskynlik geval het.

Ook militêr sou 'n grondoffensief uiters problematies gewees het, hoewel dalk nie heeltemal onuitvoerbaar nie. Albanië, wat noodwendig een van die belangrikste voorbereidingsbasisse sou gewees het, het slegs een hawetjie, dié van Durres, met slegs een taamlik sleg onderhoue teerpad na die grens met Kosovo. Om 'n aanval hiervandaan van

34 Nuusberig van Sapa-DPA, 23.4.1999, soos uitgestuur aan die pers.

55 Molly Moore en Bradley Graham: "Refugees' return is alliance's focus" (Washington Post, 17.5.1999).

56 Tim Butcher: "Mountains ground US Apaches" (The Telegraph, 22.5.1999).

57 Steven Lee Meyers: "NATO's commander reported to urge buildup of troops" (New York Times, 21.5.1999).

58 Jane Perlez: "Clinton and the Joint Chiefs to discuss ground invasion" (New York Times, 2.6.1999). 
stapel te gestuur het, sou 'n logistieke nagmerrie wees, en bowendien is die terrein in Kosovo bergagtig en moeilik. Daarby het die Amerikaners vasgestel dat die teerpad te nou was vir hul groot Abrahams tenks. ${ }^{60}$ Macedonië, die ander buurland waar ' $n$ beduidende Navo-mag hom bevind het, wou niks daarvan weet dat sy grondgebied vir 'n offensief gebruik word nie. In teorie sou ' $\mathrm{n}$ inval uit Hongarye in die noorde ideaal gewees het; die terrein is golwend en uitermate geskik vir pantser-oorlogvoering. Maar Hongarye was selfs al oor die lugaanvalle baie senuweeagtig uit vrees dat Belgrado wraak kan neem op die Hongaarssprekende minderheid net suid van die grens met Hongarye.

Wat ewenwel die belangrikste is, is die feit dat Navo die grond-opsie reg van die begin af in die openbaar van die agenda afgehaal het, en só die kans om Milosevic te intimideer verminder het. Dit is immers 'n algemeen aanvaarde strategiese en operasionele beginsel om nooit al jou kaarte op die tafel te sit en jou vyand te vertel waartoe jy bereid of nie bereid is nie. Inteendeel, die vyand moet voortdurend aan die raai gehou word om sy sielkundige en fisieke verset te ondermyn. Dié kardinale beginsel is deur Navo skromelik verwaarloos. Daar moet begrip vir die politieke werklikhede wees, maar dit hoef nie op dié manier te gebeur het nie.

Teen dié agtergrond is dit 'n suiwere oordeel van die Britse weermagstafhoof, genl. Sir Charles Guthrie, dat Navo liefs "as many options as you possibly can" moet behou: "I would like to have seen us having a well-known ground option, but that wasn't possible for various reasons. 1 personally think it probably might have made things quicker ..." ${ }^{\text {"6l }}$ Ook genl. George Joulwan, Clark se voorganger as Navo-bevelhebber in Europa, het saamgestem dat die a priori verwerping van 'n grondoffensief "had undercut the allies' leverage on Belgrade and prolonged the conflict." ${ }^{62}$

Die lugveldtog self: Omdat die politici verkeerdelik van die begin af gemeen het dat Milosevic ná 'n paar bomme die hasepad sou kies, is die lugveldtog stadig en inkrementeel aangepak en het groot irritasie in militêre kringe veroorsaak. Ooreenkomstig die foutiewe uitgangspunt is 'n driefase-plan met pouses tussen die fases uitgewerk: in die eerste fase sou Joego-Slawië se lugafweer aangeval en uitgeskakel word; dit sou dan opgevolg word met aanvalle op die Joego-Slawiese magte in Kosovo self; en in die derde fase sou daar 'n meer algemene reeks aanvalle op militêre teikens regoor die hele land wees. Die doel was uitgesproke inkrementeel: as Milosevic nie toegee nie, volg 'n volgende - erger - fase. ${ }^{63}$

Generaal Klaus Naumann, die Duitse voorsitter van Navo se militêre komitee wat tydens die veldtog met pensioen afgetree het, is só in 'n Amerikaanse koerant aangehaal: "Among the ... lessons universally taught at military academies ... is to go to war using

59 Steven Erlanger: "With Milosevic unyielding on Kosovo, NATO moved toward invasion" (New York Times, 7.11.1999).

60 Ibid.

61 BBC: "Ground troops may have shortened war", 21.6.1999 (news.bbc.co.uk)

${ }^{62}$ Eric Schmitt en Michael R. Gordon: "Shift in targets let NATO jets tip the balance" (New York Times, 5.6.1999).

63 Vgl. Jonathan Eyal: "Is Nato winning?", 13.4.1999 (news.bbc.co.uk). 
overwhelming force and maintaining an element of surprise. Both were not possible in shaping the attack on Yugoslavia because of the political sensitivities of some NATO members and the need to ensure consensus in the alliance. ${ }^{.64}$

Operasie Allied Force is dus met 'n baie klein mag van stapel gestuur, slegs sowat 300 vliegtuie, waarvan slegs 80 aanvalsvliegtuie was. Dit het vir hulle 'n volle twaalf dae geduur om dieselfde hoeveelheid vlugte uit te voer as in die eerste twaalf uur van Operasie Desert Storm in 1991. In die eerste maand of wat is 300-600 vlugte per dag uitgevoer, vergeleke met die tot 3000 per dag van agt jaar tevore. ${ }^{65}$ Nog 'n interessante statistiek: Ná sowat vyf en 'n halwe week is 12000 vlugte uitgevoer, vergeleke met die byna 100000 van 1991 in die vergelykbare stadium. In Joego-Slawië was in dié stadium sowat 4000 bomme en missiele teen 230 teikens gebruik; in Irak en Koeweit was dit 226000 teen 1200 teikens. $^{66}$ Toegegee, in Joego-Slawië was tot $70 \%$ van die bomme en missiele "slim", teryl "dom" ammunisie nog oorwegend in 1991 gebruik is. Dit dui op die manier waarop Navo Milosevic aanvanklik heel sagkens aangepak het.

Voorts het die slegte weer en digte bewolking, wat soms dae lank oor die operasionele gebied gehang het, Navo se bewegingsvryheid voortdurend aan bande gelê.

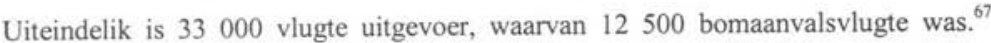
Teen einde April het die "slim" wapens begin min raak, en van toe af is "dom" ammunisie toenemend ook gebruik. ${ }^{68}$

Dié sagte benadering het ook te make gehad met die politici se - dalk oordrewe vrees dat verliese die publiek se steun vir die oorlog sou laat wegsyfer. Dus, toe Cohen die opdrag gee om met die aanvalle te begin, het hy (tot talle offisiere se verbasing) daaraan toegevoeg: "No loss of aircraft". In die eerste weke het dit beteken dat vlieëniers verbied is om laer as 15000 voet te vlieg, wat op sy beurt die akkuraatheid van hul aanvalle, veral oor die slagveld in Kosovo, aansienlik aangetas het. Eers ná sowat 'n maand is die beperking tot 12000 voet en daarna nóg laer verlig. ${ }^{69}$

In die weke wat op die aanvang van die veldtog gevolg het, het genl. Clark herhaaldelik versterkings gevra en gekry. Nog 'n teken van eskalasie was die uitbreiding van teikens. Ná die aanvanklike pogings om die Joego-Slawiese lugafweerstelsels te neutraliseer is die fokus verplaas na teikens van meer strategiese aard, soos geboue wat aan Milosevic en/of sy familie behoort het, Joego-Slawiese beeldradiosenders, olieraffinaderye en

64 Bradley Graham: "Warnings of air war drawbacks" (Washington Post, 27.4.1999).

65 Tim Butcher: "Victory over Serb forces was a close run thing" (Daily Telegraph, 5.6.1999); Steven Lee Myers en Eric Schmitt: "After one month, no NATO victory, no Serb loss" (New York Times, 24.4.1999).

${ }^{60}$ Bradley Graham: "Balkans and the Gulf: a Study in contrasts" (Washington Post, 1.5.1999).

67 Blane Harden: "Waging war on the Serbs: Old problem, new lesson" (New York Times, 6.6.1999).

68 Elizabeth Becker: "B-52's carry less accurate gravity bombs" (New York Times, 30.4.1999); Richard Norton-Taylor: "15\% of 'smart missiles' fail" (The Guardian, 30.4.1999).

69 William Drozadiak en Dana Priest: "NATO's cautious air strategy comes under fire" (Washington Post. 16.5.1999). 
kragstasies. Ook is die verbindingslinies tussen Serwië en Kosovo stelselmatig aangeval om die operasionele en taktiese vermoëns van die troepe in Kosovo aan te tas. ${ }^{70}$

'n Verdere terrein waar die lugbevelvoerders 'n vryer hand begin kry het, was in die beplanning van aanvalle en die identifikasie van teikens. In die begin moes die teikens eers deur al negentien regerings goedgekeur word, wat 'n onhoudbare beperking was. Later is toestemming gekry om slegs dié teikens waar kollaterale skade verwag kon word en in die middestad van Belgrado vir goedkeuring aan Javier Solana, sekretaris-generaal van Navo, voor te lê."

Die vraag is nou watse sukses die lugveldtog gehad het. Dit kan aan die hand van verskeie temas beantwoord word.

Ten eerste kon Navo nooit heeltemal daarin slaag om die Joego-Slawiese lugmag se operasionele vlugte teen die $\mathrm{KBL}$ in Kosovo stop te sit nie. Neem in ag dat die Navovlieëniers aanvanklik verbied is om laer as 15000 voet te vlieg, en dis duidelik dat die JoegoSlawe dankbaar gebruik gemaak het van die geleentheid om ongestraf lae aanvalsvlugte teen die KBL uit te voer. Veral die Galeb en Super Galeb ligte aanvalsvliegtuie - min of meer in dieselfde kategorie as die SA Lugmag se Impala II - kon taamlik vryelik hul ding doen. S.adm. Thomas Wilson, direkteur van inligting in die Pentagon, had waarskynlik reg toe hy aan verslaggewers gesê het die Joego-Slawe se vlugte is met slegs sowat $50 \%$ ingekort. $^{72}$

In die tweede plek moes selfs Navo-woordvoerders toegee dat die Joego-Slawe 'n verstommende vermoë aan die dag gelê het om verwoeste teikens vinnig, dikwels binne 36 uur, te herstel - en dan moes dieselfde teikens maar weer aangeval word. ${ }^{73}$

In die derde plek was een van die doelstellings van die lugoffensief om die toevoer van brandstof na weermageenhede in Kosovo stop te sit en hul operasionele vermoëns aan te tas teen die agtergrond van die grootskaalse program van etniese suiwering teen Albanese in die gebied. Dit het ook grotendeels misluk. Behalwe vir die feit dat brandstof vryelik deur hawens in Montenegro na Joego-Slawië bly vloei het ('n probleem wat ondanks talle praatjies aan Navo-kant nooit opgelos is nie), het verslae van ooggetuies op voetsoolvlak daarop gedui dat die weermageenhede in Kosovo steeds taamlik vryelik rondbeweeg het. Bowendien het die eenhede blykbaar voor die aanvang van die lugaanvalle groot hoeveelhede brandstof in Kosovo opgeslaan. Voeg nog daarby dat hulle hul swaar wapens, soos tenks en artillerie, sorgvuldig staties weggesteek het in afwagting van 'n Navo-grondoffensief. Met ander woorde, hul brandstofverbruik was minimaal, en hul voorrade ter plaatse was meer as

\footnotetext{
70 Bill Fenton: "Kill box strategy will focus air attacks" (Daily Telegraph, 19.4.1999).

7 Dana Priest en William Drozdiak: "NATO struggles to make progress from the air" (Washington Post, 18.4.1999.

72 Eric Schmitt: "Yugoslavia's tree-top war" (New York Times, 24.4.1999).

73 Dana Priest: "NATO adds targets, U.S. Troops" (Washington Post, 24.4.1999).
} 
voldoende om die veldtog van etniese suiwering (waarvoor hulle slegs vragmotors en jeeps nodig had) te voer. ${ }^{74}$

Trouens, op operasionele vlak het die Joego-Slawiese offisiere Navo se lugaanvalle ten vierde baie slim gehanteer. Hul reaksie dui daarop dat hulle goed geweet het dat hulle nie Navo op sy sterk punt, sy hoë tegnologie, kon troef nie. Hulle het dus skaars teruggeveg. Alle swaar wapens - tenks, pantsermotors, infanterie-gevegsvoertuie, artillerie - is sorgvuldig in skure, bosryke klowe, ensovoorts, versteek en die enjins so min moontlik aangeskakel. Die Navo-vlieëniers kon die wapens dus nóg met die blote oog nóg met gevorderde hittesensitiewe sensors opspoor. Foptenks is op sigbare plekke geplaas en selfs van hittebronne voorsien sodat dit op die Navo-sensors net soos egte tenks lyk. Dié fopwapens is dan uit die lug gebombardeer dat die stukke spat, wat Navo onder die waan gelaat het dat hy talle wapens vernietig het.Verder is lugafweer-radars so min moontlik aangeskakel, waardeur Navo se gesofistikeerde Harm-anti-radarmissiele feitlik nutteloos was. Intussen het die etniese suiweringsveldtog voortgegaan: 20 man op 'n vragmotor en 'n jeep met 'n betreklik primitiewe "walkie-talkie" was genoeg om 'n dorpie Albanese op die loop te jaag. ${ }^{75}$

Teen die einde van die stryd kon Navo regtig beduidend vordering begin maak - en dit was, ironies genoeg, slegs te danke aan stewels op die grond, dié van die KBL. Die KBL is in die aanvanklike suiweringsveldtog heeltemal onder die voet geloop en na die grensstrook met Albanië teruggedryf. Maar die beweging se vegters het nuwe wapens en voorrade van Navo gekry en teen helfte Mei met 'n teenoffensief begin. Toe het hulle verskeie doodsveragtende selfmoord-aanvalle teen Joego-Slawiese swaar wapens en selfs infanterieeenhede wat in die bosse geskuil het, gedoen. Die Joego-Slawe is gedwing om te reageer, en die oomblik toe hulle dít doen, is hulle gedwing om hul skuilings te verlaat. Toe was hulle vir die eerste keer in die oopte en blootgestel aan die volle woede van Navo se verwoestendakkurate bomaanvalle, wat toe inderdaad behoorlik tot hul reg gekom het. ${ }^{76}$

\section{WAAROM HET MILOSEVIC TOEGEGEE?}

Tydens die oorlog self het politici en Navo-woordvoerders op feitlik elke perskonferensie te kenne gegee dat die lugoorlog werk en dat die Joego-Slawiese weermag steier onder die hamerslae uit die lug. Dit was skromelik oordrewe.

Ná die einde van die konflik het Paul Beaver, redakteur van die invloedryke Jane's Defence Weekly, oor die BBC berig oor wat hy in die omgewing van Pristina van die terugtrekking van die Joego-Slawiese leër waargeneem het: "I counted over 50 main battle tanks, including at least six of the latest M84A (T-72G) main battle tanks. All had been in hiding. Within 24 hours of the Nato land forces entry into Kosovo, the VJ [Joego-Slawiese leër] began moving their carefully hidden armour - tanks, armoured personnel carriers, self-

74 Dana Priest en William Drozdiak: "NATO struggles to make progress from the air" (Washington Post, 18.4.1999.

75 Michael R. Gordon en Eric Schmitt: "War Games in Kosovo: Allies seek, Serbs hide" (New York Times, 7.4.1999); Michael Dobbs: "Serbs rule in Kosovo's vacant villages" (Washington Post, 17.4.1999); Philip Smucker: "Serbs are hiding tanks between houses" (Daily Telegraph, 17.5.1999).

76. William Drozdiak: “Allies need upgrade, general says" (Washington Post, 20.6.1999). 
propelled artillery and bridging units - from cover ... During the next seven days of travelling around Kosovo, I encountered only one burnt out armoured personnel carrier and two lowloaders with their back broken. There was no real evidence of a succesful Nato air operation against armoured vehicles.

"So what about the 100 plus armoured vehicles which the Nato website claims were destroyed? In Kosovo, there was no sight of them. The VJ had employed decoys - pneumatic rubber images of tanks which include heat sources for decoying thermal imaging systems carried by Nato aircraft; decoys used by Saddam Hussein and often procured from the Nato nations, including the British ... The VJ - including elements of forces which had fought in the Krajina war of 1995 (by the flags flown on the retreating tanks) - is relatively unscathed. Nato itself estimates that 45000 troops, 250 tanks, 450 armoured personnel carriers and over 400 artillery/mortar systems were withdrwan from Zone 1 alone."

Sy eindgevolgtrekking: "The moral of the story - air power is decisive but not all powerful. Battle damage assessment takes time and attacking individual targets in the field is not best done from 15000 feet." ${ }^{\prime 7}$ 'n Studie van die Britse lugmag het later tot die verstommende gevolgtrekking gekom dat slegs sowat 7 Joego-Slawiese tenks in Kosovo self deur die lugaanvalle vernietig is. ${ }^{78}$

Maar waarom het Milosevic dan wel bes gegee? 'n Deel van die antwoord, volgens 'n ná-oorlogse rekonstruksie, was dat Navo teen die einde van die konflik die Russe subtiel daarvan oortuig het dat ' $n$ grondaanval op hande is. Volgens dié siening het die Russe dié "inligting" waarskynlik aan Belgrado oorgedra en Milosevic se weerstand sielkundig help afbreek. $^{79}$

Die belangrikste deel van die antwoord moet egter waarskynlik gesoek word in die feit dat Rusland, die land waarop hy sy hoop gevestig het, hom uiteindelik in die steek gelaat het. Rusland het aanvanklik, soos hierbo beskryf is, buitengewoon fel gereageer en Navo selfs met ' $n$ Derde Wêreldoorlog gedreig. Maar namate die Weste (met Duitsland op die voorpunt) Rusland in die soeke na 'n diplomatieke oplossing ingetrek en die Russiese afgesant, Wladimir Tsjernomirdin, toegelaat het om 'n leidende rol in die onderhandelinge te speel, het die intensiteit van die Russiese regering se gevoelens afgeneem. Ten slotte het Tsjernomirdin plotseling 'n sleuteltoegewing gedoen: hy het ingestem dat Milosevic al sy troepe uit Kosovo moes onttrek; nie slegs sommige nie. Dit was die keerpunt. Binne enkele ure was pres. Martti Ahtisaari van Finland en Tsjernomirdin as bemiddelaars onderweg na Belgrado om 'n eenparige standpunt van die G-8-lande aan Milosevic oor te dra, en binne 24 uur het die Joego-Slawiese leier die handdoek ingegooi. ${ }^{80}$

\footnotetext{
77 Paul Beaver: "How Yugoslavia hid its tanks", 25.6.1999 (news.bbc.co.uk).

78 Andrew Gilligan: "RAF admits failings in Kosovo inquiry" (Daily Telegraph, 25.7.1999).

79 "Nato's game of chicken" (Newsweek, 26.7.1999).

80 William Drozdiak: "Russia's concession led to breakthrough" (Washington Post, 5.6.1999).
} 


\section{EN NOU?}

Herbewapening: Die einde van die Koue Oorlog het onder meer beteken dat verdedigingsbegrotings feitlik oral, behalwe in die Midde-Ooste en Oos-Asië, aansienlik besnoei is. Veral Navo-weermagte het kwaai deurgeloop. Dit lyk of die Kosovo-oorlog teen die agtergrond hiervan 'n kentering kan wees. Dit is in twee opsigte die geval.

In die eerste plek het die oorlog Navo se militêre vermoëns kwaai getoets. Reeds einde April het genl. Richard Hawley, wat verantwoordelik is vir magsvoorbereiding in die Amerikaanse lugmag, gekla dat daar te min "slim"-wapenvoorrade en vliegtuie is. As nog 'n oorlog in die Midde-Ooste of Asië moet uitbreek, het Hawley gesê, "I'd be hard-pressed to give them everything that they would probably ask for. There would be some compromises made." ${ }^{81}$ Onder meer moes die Amerikaners 33000 lugmagreserviste oproep en die bedanking en aftrede van vlieëniers tydelik bevries uit vrees dat daar nie genoeg mannekrag beskikbaar sou wees nie. ${ }^{82}$

Die teorie ná die Golfoorlog was dat Amerika in staat moes wees om twee streekoorloë van min of meer dieselfde omvang gelyktydig te veg en te wen. Die Kosovooorlog het gewys dat dit met die huidige militêre begroting 'n mite is.

Ten tweede het 'n gevaarlike gaping tussen die Amerikaanse en die Europese vermoëns ontstaan. Veral sedert die einde van die Koue Oorlog het die Europeërs graag agter die breë Amerikaanse skouers geskuil, maar in Kosovo het geblyk dat die Amerikaanse skouers inderwaarheid betreklik smal was. Die Europese Navo-lande bestee saam jaarliks sowat $\$ 140$ miljard aan verdediging teenoor die Amerikaanse \$290 miljard, of, anders gestel, $2,1 \%$ van hul bruto binnelandse produk vergeleke met die $3,2 \%$ in Amerika. ${ }^{83}$

Die Europese leemtes is veral hul tekort aan strategiese mobiliteit - hulle is grotendeels afhanklik van die yslike Amerikaanse C-5 en C-17 transportvliegtuie; hul eie C130 's en C-160's is te min en te klein - en hoë tegnologie Lt.-genl. Michael C. Short, wat in bevel van die beplanning van die Navo-lugveldtog was, het gesê die tekortkomings van die Europese vliegtuie was só erg (veral rakende nagvisievermoë en lasergeleide wapenstelsels) dat hy hul deelname aan die veldtog tot die minimum beperk het om moontlike verliese te voorkom. Short het gesê tensy die saak reggestel word, sal Navo binnekort "second- and third-team members" hê wat nie in staat is om aan dieselfde missies as die Amerikaners deel te neem nie. ${ }^{84}$ Dis basies waarom Amerikaanse vliegtuie tot $80 \%$ van al die missies in die oorlog uitgevoer het. ${ }^{85}$

81 Bradley Graham: "General says U.S. readiness is ailing" (Washington Post, 30.4.1999).

82 Eric Schmitt: "War stretches Pentagon's resources" (New York Times, 2.5.1999); Steven Lee Myers: "Air Force is told to halt fliers' retirement" (New York Times, 27.5.1999).

83 Roger Cohen: "Dependent on U.S. now, Europe vows defense push" (New York Times, 12.5.1999); Patrick Wintour: "Stronger Britain emerges as guns fall silent" (The Observer, 13.6.1999).

84 William Drozdiak: "Air war exposed arms gap within NATO" (Washington Post, 28.6.1999).

"ss Mark Thompson: "How we fight" (Time, 26.4.1999). 
Die Europese Navo-lede het ook self tot dié ontdekking gekom, en hul ministers van buitelandse sake en verdediging nog tydens die konflik na 'n vergadering in Bremen gestuur om daar ooreen te kom om die gaping te verklein. ${ }^{86}$

'n Nuwe internasionale orde: Alles dui daarop dat die oorlog in Kosovo die grens vorm tussen 'n heel definieerbare historiese fase, die ná-Koue-Oorlogse era (wat met die val van die Berlynse Muur op 9 November 1989 ingelui is), en een waarvan die meeste eienskappe nog deur die newels van die toekoms verhul word. Tog is dit nie onbillik om nou reeds sekere verwagte elemente te identifiseer nie.

Die bipolariteit van die Koue Oorlog was die mees stabiele stelsel wat die wêreld nóg geken het. In 1988, vlak voor sy einde, het hy die vorige rekord van 'n tyd sonder grootskaalse oorlog, dié tussen 1871 en 1914, verbygesteek. Die rede daarvoor was die magsewewig tussen die twee blokke, wat bowendien aangehelp is deur die aanwesigheid van genoeg kernwapens aan albei kante om alle lewe op aarde teoreties twintig keer uit te wis. Albei kante wis dat 'n aanval van die een oombliklik op 'n teenaanval van die ander sou uitloop en dus op wedersydse selfmoord sou neerkom. Maar na aanleiding van die Kubaanse krisis van 1962, wat baie amper op 'n kernoorlog uitgeloop het, het die twee supermoondhede teen die einde van die sestigerjare stilswyend ooreengekom om sake nie verby 'n bepaalde punt te laat eskaleer nie. ${ }^{87}$

Dié - weliswaar perverse - stabiliteit van die Koue Oorlog het nou verdwyn; die bipolêre stelsel is opnuut deur 'n multipolariteit vervang. Pleks van twéé pole is daar nou minstens vyf, dalk ses: Amerika, die Europese Unie, Rusland, China, Indië en dalk in die toekoms ook Brasilië. In die eerste jare ná die einde van die Koue Oorlog was daar nog 'n naïewe verwagting dat almal nou braaf en demokraties sou wees en dat samewerking konfrontasie kon vervang, maar later in die dekade het dit al begin uitrafel. Dit lyk of die Kosovo-oorlog die finale spyker in die doodskis van dié verwagting kan wees.

Dit is deels te wyte aan die intrinsieke onstabiliteit van 'n multipolêre stelsel. Konflikbeheersing tussen twéé pole, wat bowendien min of meer ewe sterk is, is baie eenvoudiger as wanneer vyf of ses op die toneel is.

Maar dit word deur nog 'n faktor vererger. Nog diep onder die indruk van die ongelooflike bloedvergieting, menslike ellende en ontsaglike verwoesting van 1939-'45, het die wêreld se oorwinnaars in 1945 in San Francisco byeengekom vir die stigting van die Verenigde Nasies en 'n Handves - die grondwet van die nuwe organisasie - opgestel om die soort anargie wat die geskiedenis voor dié tyd gekenmerk het, teen te gaan. Alle lidlande het hulle vrywillig hiertoe verbind. In artikel 2 is aggressiewe oorlog in feite onwettig verklaar:

"2.3 All Members shall settle their international disputes by peaceful means in such a manner that international peace and security, and justice, are not endangered.

${ }^{86}$ Roger Cohen: "Dependent on U.S. now, Europe vows defense push" (New York Times, 12.5.1999).

87 Vgl. Aleksandr Fursenko en Timothy Naftali: 'One Hell of a Gamble': Khrushchev, Castro, Kennedy and the Cuban Missile Crisis, 1858-1964 (Londen, Pimlico, 1999). 
"2.4 All Members shall refrain in their international relations from the threat or use of force against the territorial integrity or political independence of any state ..."

Die reg op individuele of kollektiewe selfverdediging teen ' $n$ onuitgelokte aanval word in artikel 51 gehandhaaf. En in artikel 42 (saamgelees met artikel 53) word één uitsondering op die verbod op aggressiewe oorloë gemaak: die Veiligheidsraad mag toestemming gee aan een of meer moondhede of 'n internasionale streekorganisasie om oorlog te maak teen 'n ander moondheid wat die internasionale vrede en stabiliteit bedreig.

Die doel hiervan was om oorlog te beperk en 'n duidelike volkeregtelike grondslag te gee, pleks van die anargie wat die internasionale politiek voor 1945 gekenmerk het.

Die praktiese toepassing van die artikels was weliswaar nie ideaal nie. In die praktyk het elkeen van die vyf permanente lede van die Veiligheidsraad (Amerika, die Sowjet-Unie, China, Frankryk en Brittanje) hul vetoreg gebruik wanneer dit hul belange gepas het. Die vrede is eerder deur die magsewewig tussen Navo en die kommunistiese Warschau-pakt as deur respek vir die Handves gehandhaaf. Tog was die bestaan van die artikels as deel van die volkereg belangrik, want dit het 'n ideaal bevat wat in 'n nuwe situasie - soos die terugkeer na 'n multipolariteit - van groot waarde kon wees.

Die nuwe neiging, wat met die oorlog in Kosovo die eerste keer uitgebars het, is om die Handves eenkant toe te vee, om oorlog te maak om soewereine state te dwing om hul burgers ooreenkomstig die idees van een groep, in dié geval Navo, oor menseregte te behandel.

'n Voorstander van die nuwe benadering, prof. Michael J. Glennon, hoogleraar in die regte aan die Universiteit van Kalifornië, skryf in 'n artikel in die invloedryke tydskrif Foreign Affairs dat die Handves gebaseer was op "a premise that is simply no longer valid the assumption that the core threat to international security still comes from interstate violence. This assumption is no longer true." Hy sê die eintlike probleem deesdae is "intrastate violence, which is not effectively addressed by the Charter" - gevalle soos Haïti, Somalië, Rwanda en Bosnië.

Hy wys op nog 'n aspek: "The West's new rules of thumb on intervention accord less deference to the old idea of sovereign equality - the erstwhile notion that all countries, large or small, are equal in the eyes of the law. The new posture recognizes the hollowness of this concept, accepting that all states are not in fact the same in their power, wealth, oor commitment to human rights or peace." Maar - en dit is belangrik - hy gee dan toe dat "the new regime will not represent the true rule of law" en wys op die voordele van kodifisering. "It is therefore dangerous for NATO to unilaterally rewrite the rules by intervening in domestic conflicts on an irregular, case-by-case basis ... The real test of a new system will be whether succeeding generations throughout the community of nations - not simply in centers of wealth and power - believe the system and the actions it prescribes to be just. Case-by-case decisions to use force, made by the users alone, are not likely to generate such support." 88

${ }^{88}$ Michael J. Glennon: "The New Interventionism" (Foreign Affairs, 78/3, Mei/Junie 1999, pp. 2-7). 
Dit is inderdaad die kern van die saak. As 'n nuwe element dan tot die volkereg toegevoeg moet word, moet dit ordelik en met die steun van die grootste deel van die internasionale gemeenskap gebeur. Één groep, hoe magtig en invloedryk ook al, kan dit nie eensydig doen nie.

Navo het dit nie durf waag om Rusland na aanleiding van sy hernieude ingryping in Tsjetsjnja te tug nie; die land is te sterk (Joego-Slawië was maar 'n vulletjie). Sal Navo troepe na Rwanda of elders in Afrika stuur as dáár weer ' $n$ volksmoord dreig of plaasvind? Jesse Jackson het dalk 'n punt beet: "When the ethnic Albanians are driven out of Kosovo, our government and NATO comes to defend them. In Sierra Leone, there is only an Africa crisisresponse team, leaving the impression that there is something unsafe about risking a life to save an African." ${ }^{89}$

'n Mens kan selfs 'n enigsins absurde (of is dit?) voorbeeld noem: Wat sal die Weste se reaksie wees as - sê maar - China sy voorbeeld volg en Indië aanval oor dié se hardhandige pogings om die Moslem-meerderheid in Kasjmir te keer om af te skei en by Pakistan aan te sluit? Of as Turkye en die Turkssprekende Sentraal-Asiatiese republieke China gryp oor dié se weiering om die Turkssprekende provinsie Xinjiang groter outonomie toe te laat? Natuurlik is daar groot praktiese verskille. Maar waar is die prinsipiële verskil? Inteendeel, in die praktyk lyk dit eerder na die kissie van Pandora, waaruit allerlei vreeslike duiwels, soos onstabiliteit, konflik en oorlog, tevoorskyn kan kom.

Die waarheid van dié stelling blyk uit die felle reaksie van veral Rusland en China, wat albei rede het om die nuwe benadering te vrees. Daar is rede om aan te neem dat Rusland in die toekoms al hoe meer betrokke gaan raak by sy eie periferie - gebiede soos Tsjetsjnja, maar ook die olieryke en strategies belangrike Sentraal-Asiatiese republieke wat einde 1991 van hom afgeskei het. Hiervoor sal die Kremlin 'n vrye hand wil hê.

Bowendien, skryf die gedugte Henry Kissinger, "Russia may have thrown in the towel on seeking to shape the immediate outcome significantly. But it feels deeply humiliated; Kosovo has become a public symbol of Russia's loss of influence and public degradation by the West." 90

Dié ontnugtering met die Weste - en die Westerse ekonomiese stelsel, die kapitalisme - het al 'n tyd lank aangekom. Maar die oorlog in Kosovo, en die (soos die Russe dit subjektief ervaar het) minagtende wyse waarop die Weste hulle behandel het, was die laaste strooi. Sergei Rogof, direkteur van die Instituut vir die Studie van Amerika en Kanada in Moskou, sê die Russe het verwag dat Amerika miljarde dollar sou bestee om Rusland se oorgang na die vrye mark te vergemaklik. Dat dit nie gebeur het nie, het hulle as verraad ervaar. "The outcome created the perception that the United States was doing it on purpose trying to undermine Russia as an economic and political competitor." Die ooswaartse uitbreiding van Navo het die gevoel versterk, volgens Rogof. "Russians felt that we ended the Cold War and started to behave nicely by dissolving the Warsaw Pact, withdrawing troops,

\footnotetext{
89 Jesse Jackson: "A tale of two countries" (Newsweek, 7.6.199).

90 Henry A. Kissinger: "As the cheers fade" (Newsweek, 21,6.1999).
} 
cutting arms. And thus the very maintenance of NATO was seen as strange. But the enlargement of NATO, with NATO absorbing former Soviet clients - that was interpreted as a symbol of Western mistrust toward Russia, and some even said hostile intentions."

En die oordeel van André Piontowski, 'n Russiese politieke ontleder, was skerp: "Anti-Americanism may be becoming the Russian national idea that we have been searching for " ${ }^{\text {"92 }}$ Alles dui dus daarop dat Rusland sy liefdesverhouding met die Weste en Westerse waardes beëindig het: die paradigma van 'n kapitalistiese demokrasie, so lyk dit, word verruil vir 'n nuwe paradigma, dié van die Russiese nasionalisme.

Die betekenis hiervan word só deur Henry Kissinger verduidelik: "[I]n Russia, nationalism has historically been missionary and imperial ... Russian writers have fare more justified Russia's outward thrust as a messianic vocation. Russia on the march has rarely shown a sense of limits; thwarted, it tended to withdraw into sullen resentment. For most of its history, Russia has been a cause looking for opportunity ...,93

Die Russiese geskiedenis is nie aan die kant van diegene wat optimisties oor die oorlewing van die huidige half-demokrasie in die land is nie. Regdeur die Russiese geskiedenis is daar 'n konstante patroon: 'n "goeie tsaar" kom aan die bewind en liberaliseer effens. Die Russe, met hul natuurlike neiging tot anargie, kan die nuutgevonde vryheid nie hanteer nie, ruk handuit, en 'n volgende "slegte tsaar" moet die verdrukking met verdubbelde woede en wreedheid herstel. Só gesien was Iwan die Verskriklike en Josef Stalin voëls van eenderse vere, net soos Alexander II en Michail Gorbatsjof/Boris Jeltsin.

Daar is verdere aanduidings dat die militêre establishment vir die eerste keer sedert die Russiese Revolusie 'n greep op die formulering van beleid gekry het. Die uitdagende besluit om die lughawe van Pristina deur Russiese valskermsoldate te laat beset voordat Britse troepe daar kon aankom en nie deur die Britte geïntimideer te word nie, is volgens berigte eensydig deur Russiese generaals geneem. Jeltsin is glo nie geraadpleeg nie; hy is pas vlak voor die operasie ingelig. Sy eerste minister, Sergei Stepasjin, die minister van buitelandse sake, Igor Iwanof, selfs die minister van verdediging, Wiktor Sergejef, het niks geweet nie. ${ }^{94}$

Wat dit des te ontstellender maak, is die feit dat die Sowjet-weermag, net soos dié in die Westerse demokrasieë, sedert die Russiese Revolusie van 1917 onomwonde ondergeskik aan die politici was. Dit was Lenin en Stalin, Chroesjtsjof en Brezjnjef wat die besluite geneem het, nie Timosjenko en Zjoekof nie. Met 'n swak, doodsiek leier soos Jeltsin - wat meer in sy eie politieke oorlewing as enigiets anders belangstel - kan die militêre invloed in Rusland dalk ongesond groot word. Selfs die moontlikheid van 'n militêre diktatuur vorentoe kan nie uitgeskakel word nie.

91 Michael Wines: "Hostility towards U.S. is now popular in Moscow" (New York Times, 12.4.1999).

92 Ibid.

93 Henry A Kissinger: Diplomacy: (New York. Simon \& Schuster, 1994), p. 25.

${ }^{94}$ Andrew Harding: "Yeltsin and his generals". 19.6.1999 (news.bbc.co.uk). 
Wat China betref, het die Kosovo-oorlog eweneens tot 'n waterskeiding aanleiding gegee. Die foutiewe bomaanval op die Chinese ambassade in Belgrado was 'n katalisator en vir Beijing waarskynlik 'n welkome aanleiding om 'n anti-Amerikaanse nasionalisme op te wek en mede daardeur sy eie diktatuur te beveilig.

"When Chinese strategists peek out from behind their Great Wall these days," het die Washington Post ná die einde van die oorlog uit Beijing berig, "this is what they see: an American-spun web of security relationships from Kosovo to Kazakhstan, Mongolia to Manila, tightening around China's borders. Chinese strategists have proclaimed for two decades that peace will reign in Asia and economic development would be the priority in Beijing. But prompted by the May 7 bombing of the Chinese embassy in Yugoslavia and, before that, U.S. moves to bolster military relations with China's bordering states, the strategists are rethinking their security doctrine in a move that could have significant implications for security in Asia and the Pacific." Onder meer is gesprekke aan die gang om 'n strategiese bondgenootskap tussen Rusland en China aan die gang te kry, en volgens "a Chinese source" word daar gedebatteer oor die moontlikheid om die vervaardiging van Chinese kernwapens te hervat. "The attack," het anonieme Chinese generaals glo gesê, "has convinced the Chinese military that the United States and NATO are concocting even greater conspiracies against China." 95

Wat 'n mens jou onwillekeurig laat afvra: was dié sekerlik onbedoelde gevolge van die ingryping in Kosovo en die nuwe menseregte-leer - die vervreemding van Rusland en China - die moeite werd? Dit lyk of dit 'n goed bedoelde leer is met hoë en pragtige ideale waarteen niemand met 'n liberaal-demokratiese oortuiging regtig iets prinsipieels kan inbring nie. Maar as die negatiewe gevolge van dié sprong in die duister, wat toenemend onbekook en ondeurdag lyk, daarteen afgeweeg word, lyk dit of die wêreld beter daaraan toe sou gewees het as Navo liewer op die verbetering van sy betrekkinge met deurslaggewende groot moondhede soos Rusland en China gekonsentreer en die onoplosbare probleme van die Balkan aan die inwoners van dié streek oorgelaat het. Vir die Kosovaarse Albanese is dit slegte nuus; vir die res van die wêreld waarskynlik nie.

\section{ENKELE LESSE}

Ten slotte nog by wyse van samevatting enkele heel voorlopige gedagtes oor wat uit die oorlog geleer kan word.

- Die oorlog het, so lyk dit, die wêreldgeskiedenis 'n nuwe fase laat betree, 'n fase waarin die stabiliteit van die Koue Oorlog en die eerste jare daarna heel waarskynlik deur 'n toenemende onstabiliteit vervang kan word. Dit is ten eerste natuurlik te wyte aan die inherente onstabiliteit van die multipolêre stelsel, maar - mits Navo se nuwe internasionale menseregte-leer geen eendagsvlieg is nie - ook aan die eensydige (en volgens ander state arrogante) wyse waarop dit toegepas is. Veral die openlike verbreking van die VN-Handves is kommerwekkend, en kan die internasionale onstabiliteit vererger. Hiervan sal buitelandse beleids- en verdedigingsbeplanners in

95 John Pomfret: "China rethinks security after NATO attack" (Washington Post, 11.6.1999). 
Suid-Afrika deeglik kennis moet neem, want die land sal moet besluit hoe hy hom in die toekoms moet posisioneer. Ook teen die agtergrond van die internasionale neiging om meer aan verdediging te bestee sal Suid-Afrika hom moet afvra of hy genoeg doen om sy eie nasionale veiligheid te waarborg.

- Die oorlog kan helaas aanleiding gee tot 'n besonder gevaarlike oortuiging dat 'n gewapende konflik sonder verliese (altans aan Navo se kant) gevoer kan word. Veral vir staatsmanne en -vroue sonder militêre ondervinding kan dit baie verleidelik word om vir elke bagatel na die wapen te gryp, pleks van om konflikte deur diplomasie of ander vreedsame middele op te los.Dit het dié keer weens die unieke samekoms van 'n aantal faktore min of meer geluk, maar die kans is klein dat die faktore weer in dié kombinasie sal voorkom.

- Oorlog, veral 'n ongedwonge oorlog, is nie perdekoop nie. Politici moet nie ligsinnig in 'n konflik indons nie. Voordat hulle besluit om tot so iets toe te tree, moet minstens vier belangrike stappe nagekom word. Ten eerste moet daar absolute helderheid wees oor die politieke doel wat hulle wil nastreef, want dit bepaal alles wat daarop volg. In die tweede plek moet daar gekyk word na die waarskynlike prys wat betaal moet word - geld, krygsmateriaal, menselewens, politieke nadele. Daaruit volg logies die derde stap, die vraag of die land in stáát is om daardie prys te betaal. As hy nie is, nie moet hy terugkeer na die eerste stap en die politieke doel afwaarts aanpas. Ten slotte moet hy vasstel of hy gewillig is om die prys te betaal. Indien nie, moet hy weer na stap een terugkeer. Alles dui daarop dat dié besluitnemingsproses nié ten opsigte van Kosovo nagekom is nie.

- Aansluitend hierby kan daar nie uit die verloop van die oorlog afgelei word dat lugkrag die debat gewen het en dat oorloë nou uit die lug, sonder stewels op die grond, gewen kan word nie. Strategies het die lugaanvalle Milosevic beslis seergemaak, maar dit was uiteindelik die feit dat die Russe, op wie hy sy hoop gevestig het, hom in die steek gelaat het wat hom laat ingee het, nie soseer die pyn wat hy weens die lugaanvalle moes verduur nie. Operasioneel kon die lugaanvalle nie die veldtog van etniese suiwering keer nie; dit het voortgegaan byna asof daar geen lugveldtog was nie. Die Joego-Slawiese leër in Kosovo het pas in die laaste week of twee van die stryd begin seerkry, en toe was dit omdat die KBL hom op die grond in die oopte gejaag en kwesbaar vir die lugaanvalle gemaak het. Selfs dit in ag nemende, dui alles daarop dat die Joego-Slawiese leër wat Kosovo in Junie verlaat het, absoluut geen verslane mag was nie.

- Wie het die oorlog gewen? Navo, natuurlik. Die bondgenootskap het immers sy strategiese doel - die stopsit van die etniese suiweringsveldtog, die uitdryf van die Joego-Slawiese magte uit Kosovo en die terugkeer van die Albanese vlugtelinge bereik. Maar teen welke prys? Die ironie is dat Albanië in die derde eeu v.C. die tuiste was van 'n sekere koning Pirrhus, wat verskeie veldtogte in die naburige Italië gevoer en verskeie oorwinnings behaal het. Aan die feit dat dié oorwinnings sy land ten slotte heeltemal uitgeput gelaat het, ontleen ons vandag die begrip Pirrhiese 
oorwinning - een wat die oorwinnaar so seermaak dat hy maar liewer in die eerste plek nie met die bakleiery moes begin het nie. Dit is die ware aard van Navo se oorwinning.

Ten slotte twee aanhalings wat die kern van die saak goed weergee.

Die Navo-leiers, skryf The Economist, "launched the first war in history said to be in pursuit of principle, not interest. The trouble was that they had never intended to do more than drop a few bombs. Then, when a few bombs proved inadequate, they found they had stumbled into a war they did not mean to fight, had not prepared to fight and were not willing to fight, at least with men who might get killed. This is not the stuff of nobility. The Kosovo war turned out, as wars generally do, a mess." ${ }^{96}$

Die tweede: Die nuwe internasionale orde, sê Henry Kissinger tereg, "is a question of a group of nations claiming to apply a universal jurisdiction which is not shared by the majority of mankind. It will have to be modified." ${ }^{97}$

Geen wonder nie dat Alistair Horne so "utterly miserable" oor die oorlog in Kosovo was.

Nota: Dr. Leopold Scholtz is senior adjunk-redakteur van Die Burger. Hy is tewens besoekende professor in die geskiedenis aan die Universiteit van Stellenbosch en kaptein in die SA Leër se Reserwemag.

Drs. Ingrid Scholtz doseer aan die Departement Joernalistiek van die Universiteit van Stellenbosch.

\footnotetext{
"Messy war, messy peace" (The Economist, 12,6.1999).
}

97 Boris Johnson: “Cold War warrior scorns new morality" (Daily Telegraph, 28.6.1999). 